\title{
Impacts of urban land-surface forcing on ozone air quality in the Seoul metropolitan area
}

\author{
Y.-H. Ryu ${ }^{1}$, J.-J. Baik ${ }^{1}$, K.-H. Kwak ${ }^{1}$, S. Kim ${ }^{2}$, and N. Moon ${ }^{3}$ \\ ${ }^{1}$ School of Earth and Environmental Sciences, Seoul National University, Seoul, South Korea \\ ${ }^{2}$ Division of Environmental, Civil and Transportation Engineering, Ajou University, Suwon, South Korea \\ ${ }^{3}$ Korea Environment Institute, Seoul, South Korea
}

Correspondence to: J.-J. Baik (jjbaik@snu.ac.kr)

Received: 31 July 2012 - Published in Atmos. Chem. Phys. Discuss.: 28 September 2012

Revised: 8 January 2013 - Accepted: 22 January 2013 - Published: 25 February 2013

\begin{abstract}
Modified local meteorology owing to heterogeneities in the urban-rural surface can affect urban air quality. In this study, the impacts of urban land-surface forcing on ozone air quality during a high ozone $\left(\mathrm{O}_{3}\right)$ episode in the Seoul metropolitan area, South Korea, are investigated using a high-resolution chemical transport model (CMAQ). Under fair weather conditions, the temperature excess (urban heat island) significantly modifies boundary layer characteristics/structures and local circulations. The modified boundary layer and local circulations result in an increase in $\mathrm{O}_{3}$ levels in the urban area of $16 \mathrm{ppb}$ in the nighttime and $13 \mathrm{ppb}$ in the daytime. Enhanced turbulence in the deep urban boundary layer dilutes pollutants such as $\mathrm{NO}_{\mathrm{x}}$, and this contributes to the elevated $\mathrm{O}_{3}$ levels through the reduced $\mathrm{O}_{3}$ destruction by $\mathrm{NO}$ in the $\mathrm{NO}_{\mathrm{x}}$-rich environment. The advection of $\mathrm{O}_{3}$ precursors over the mountains near Seoul by the prevailing valley-breeze circulation in the mid- to late morning results in the build-up of $\mathrm{O}_{3}$ over the mountains in conjunction with biogenic volatile organic compound (BVOC) emissions there. As the prevailing local circulation in the afternoon changes to urban-breeze circulation, the $\mathrm{O}_{3}$-rich air masses over the mountains are advected over the urban area. The urban-breeze circulation exerts significant influences on not only the advection of $\mathrm{O}_{3}$ but also the chemical production of $\mathrm{O}_{3}$ under the circumstances in which both anthropogenic and biogenic (natural) emissions play important roles in $\mathrm{O}_{3}$ formation. As the air masses that are characterized by low $\mathrm{NO}_{\mathrm{x}}$ and high $\mathrm{BVOC}$ levels and long $\mathrm{OH}$ chain length are advected over the urban area from the surroundings, the ozone production efficiency increases in the urban area. The relatively strong vertical mixing in the urban boundary layer
\end{abstract}

embedded in the sea-breeze inflow layer reduces $\mathrm{NO}_{\mathrm{x}}$ levels, thus contributing to the elevated $\mathrm{O}_{3}$ levels in the urban area.

\section{Introduction}

Air pollution continues to be a critical problem in major cities around the world (Banta et al., 2005). Urban areas are often characterized by the presence of large emissions of pollutants such as nitrogen oxides $\left(\mathrm{NO}_{\mathrm{x}}=\mathrm{NO}+\mathrm{NO}_{2}\right)$ and volatile organic compounds (VOCs) (Wood et al., 2009). In the presence of sunlight, secondary pollutants such as ozone $\left(\mathrm{O}_{3}\right)$ are formed through photochemical reactions involving $\mathrm{NO}_{\mathrm{x}}$ and VOCs (e.g. Duncan et al., 2010). The occurrence of high $\mathrm{O}_{3}$ episodes is related in a complex way to various factors that include emissions of primary pollutants, chemical reactions, and meteorological conditions.

Local circulations that arise from surface heterogeneity have been regarded as important factors governing the advection and diffusion of pollutants (e.g. Fast et al., 2000; Makar et al., 2010). In urbanized basin areas, the impacts of mountain-/valley-breeze circulations on air quality have been extensively investigated (e.g. Lu and Turco, 1994; Fast and Zhong, 1998; Fast et al., 2000). The upslope wind in the daytime can transport pollutants toward mountains, and the pollutants can be blown back over a city or vented out of the boundary layer into the free atmosphere (Fast et al., 2000). In addition, the pollutants vented out of the boundary layer can be entrained downward as the boundary layer grows, leading to an increase in pollutant concentration at the surface (Fast and Zhong, 1998). 
In urbanized coastal areas, sea-/land-breeze circulations and the associated recirculation of pollutants can play important roles in the production and accumulation of $\mathrm{O}_{3}$. Elevated $\mathrm{O}_{3}$ levels in urbanized coastal areas have been observed and modeled in a number of studies, and it has been shown that the recirculation of pollutants by sea-/land-breeze circulations is largely responsible for the elevated $\mathrm{O}_{3}$ levels (e.g. Banta et al., 2005; Oh et al., 2006; Levy et al., 2008; Martins et al., 2012). As $\mathrm{O}_{3}$ precursors emitted from urban areas are advected over water by land-breeze circulation and thereby $\mathrm{O}_{3}$ is photochemically produced over water where it does not readily deposit, the $\mathrm{O}_{3}$-rich air mass can be advected onto land by sea-breeze circulation (Martins et al., 2012). Makar et al. (2010) reported a similar phenomenon in which the recirculation of pollutants by lake-breeze circulation leads to elevated $\mathrm{O}_{3}$ levels in the southern Great Lakes region of North America.

In spite of the great concern about the impacts of local circulations arising from natural surface heterogeneities on air quality, the impacts of urban-induced/-modified local circulation have received less attention. Considering the poor air quality in cities where pollutant emissions are high, the impacts of urban land-surface forcing on local circulations and air quality need to be better understood. It is known that under favorable weather conditions the horizontal temperature difference between urban and rural areas (i.e. urban heat island (UHI)) can induce a local circulation called the urbanbreeze circulation (or UHI circulation). The urban-breeze circulation, characterized by convergent flow toward the city center in the lower boundary layer and divergent flow toward the surroundings in the upper boundary layer, has been observed in many cities such as St. Louis, USA (Wong and Dirks, 1978), and Toulouse, France (Hidalgo et al., 2008), and also examined in numerical studies (e.g. Lemonsu and Masson, 2002; Miao et al., 2009). A few studies have addressed the impacts of urban land-surface forcing on local meteorology and air quality. Sarrat et al. (2006) demonstrated that enhanced turbulence owing to the UHI effect in Paris, France, dilutes pollutants more inside the deeper boundary layer. Some studies of the impacts of urbanization on air quality have reported that $\mathrm{O}_{3}$ concentration in cities can increase by several ppb owing to urbanization that causes increases in temperature and boundary layer height, a reduction in wind speed, and so on (Civerolo et al., 2007; Wang et al., 2007, 2009; Jiang et al., 2008). However, the previous studies did not pay enough attention to the impacts of urbaninduced/-modified local circulation on air quality.

In this study, we aim to examine the impacts of urban landsurface forcing on ozone air quality in the Seoul metropoli$\tan$ area, South Korea. Seoul is a megacity with a population of about 10 million, and the Seoul metropolitan area is the largest urban area in South Korea. The geographical features in the study area are complex. Seoul is located in a basin surrounded by mountains to the north, east, and south and is open to the Yellow Sea to the west. That is, the study area is characterized by an urbanized basin and coastal area. Thus, in the study area, several local circulations, such as urbanbreeze, valley-breeze, and sea-breeze circulations, can develop and interact with each other under favorable weather conditions, which in turn can substantially affect air quality. Ryu and Baik (2012) conducted a case study of daytime local circulations and their interactions in the Seoul metropolitan area using a high-resolution mesoscale atmospheric model (with a finest horizontal grid size of $0.333 \mathrm{~km}$ ). They showed that urban-breeze circulation strongly interacts with valleybreeze and sea-breeze circulations under a weak synopticwind condition. The same case in which elevated $\mathrm{O}_{3}$ levels occurred is chosen in the present study. It is expected that changes in boundary layer characteristics/structures and local circulations caused by urban land-surface forcing have considerable impacts on pollutant concentrations. To examine the impacts of urban land-surface forcing on local meteorology and air quality, a hypothetical simulation in which the urban surface is replaced with a non-urban surface (cropland) is carried out and results of the hypothetical simulation are compared with those of the baseline simulation.

\section{Methodology}

\subsection{Meteorology modeling system}

As a meteorological model, the Weather Research and Forecasting (WRF) model version 3.2 (Skamarock et al., 2008) is employed. For a better representation of urban-surface characteristics such as large thermal inertia and increased drag owing to buildings, a more physically based urban canopy model (Seoul National University Urban Canopy Model (SNUUCM), Ryu et al., 2011) is adopted, which is coupled with the WRF model. The Yonsei University planetary boundary layer scheme (Hong et al., 2006) is used as a boundary layer parameterization scheme, and other experimental setup and physical parameterization options used in the present study are the same as those used in Ryu and Baik (2012), except for the domain with the horizontal grid size of $0.333 \mathrm{~km}$. Four domains with horizontal grid sizes of 27, 9, 3, and $1 \mathrm{~km}$ are considered. There are 43 vertical layers below the model top of $20 \mathrm{hPa}$ and 16 vertical layers below $2 \mathrm{~km}$. The size of the lowest vertical grid is $\sim 35 \mathrm{~m}$. The same case, 24 June 2010, as that chosen in Ryu and Baik (2012) is also chosen in the present study. The model is integrated for $72 \mathrm{~h}$ from 09:00 LT (= UTC +9 h) 22 June 2010. The National Centers for Environmental Prediction (NCEP) final analyses are used for the initial and boundary conditions. To represent more realistic urban land use/land cover (LULC) in the study area, an LULC data set based on Geographic Information System (GIS) data is used (Fig. 1b). Further description of the LULC data set is given in Ryu and Baik (2012). To examine the impacts of urban land-surface forcing, an additional 
(a)

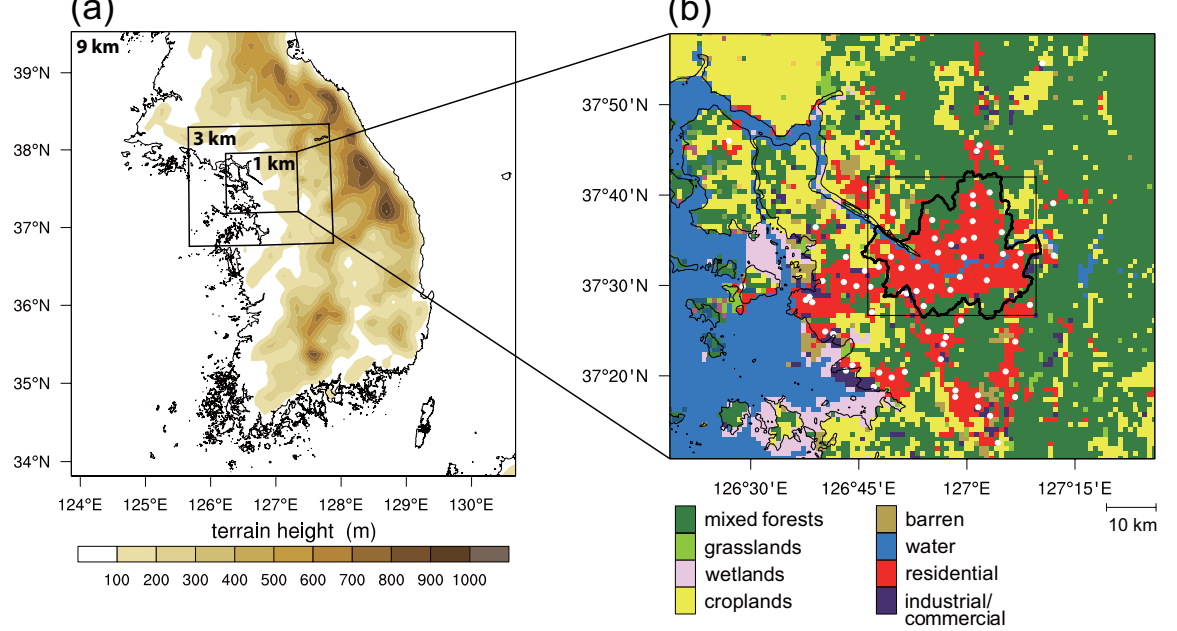

(c)
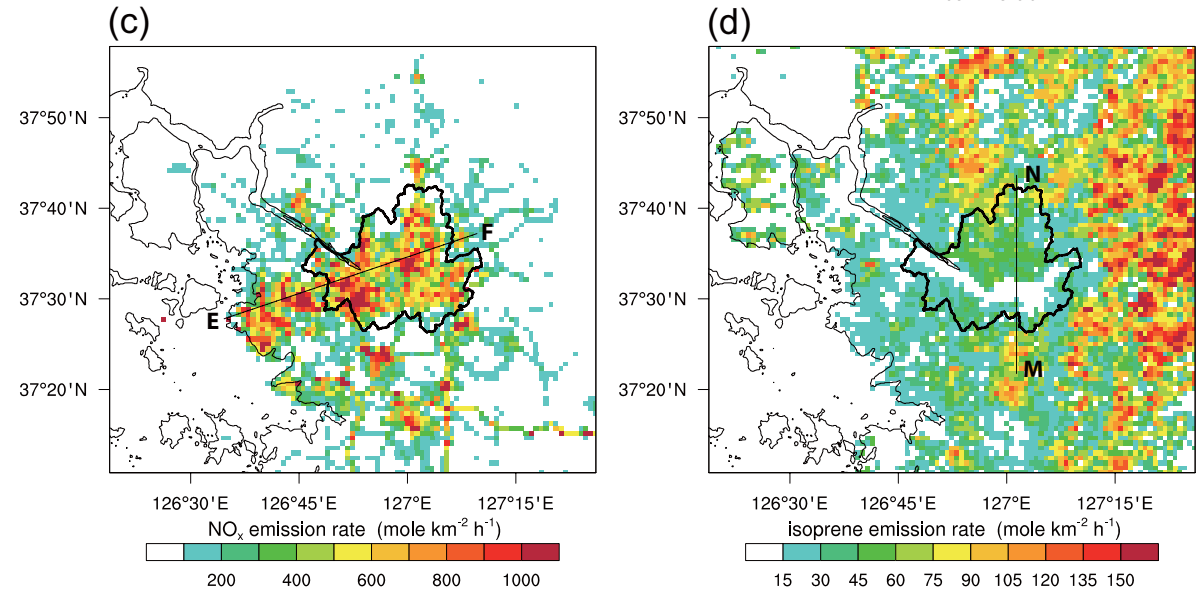

Fig. 1. (a) Domain configuration of the CMAQ model simulation with terrain height (shaded). (b) Land use/land cover (LULC) in the innermost domain. Only dominant LULCs are indicated in the legend. The white circles indicate air quality monitoring sites whose data are used for the validation. The rectangle indicates the urban analysis area, and the thick line indicates the administrative boundary of Seoul. (c) $\mathrm{NO}_{\mathrm{x}}$ and (d) isoprene emission rates at 15:00 LT 24 June 2010 in the innermost domain.

simulation in which the urban LULC is assumed to be cropland LULC is performed.

\subsection{Air quality modeling system}

The Community Multiscale Air Quality (CMAQ) modeling system has been designed to represent multiple air quality issues (Byun and Schere, 2006). In the present study, the CMAQ model version 4.7.1 is used. The output of the WRFSNUUCM simulation is provided as the meteorological input for the air quality simulation. In the air quality simulation, three domains with horizontal grid sizes of 9,3 , and $1 \mathrm{~km}$ are adopted (Fig. 1a). The initial and boundary conditions for the outermost domain are provided by the default profiles implemented in the CMAQ model. The default profiles for some relevant species are given in Table S1 (Supplement). The output of each outer domain is then used as the boundary conditions for each inner domain. The number of vertical layers used is 29 , and the same vertical layers from the lowest layer to the 22nd layer (eta level $=0.63$ ) as those used in the WRFSNUUCM simulation are used. The model is also integrated from 09:00 LT 22 June 2010, and the simulation data of 24 June 2010 are used for analysis. The Statewide Air Pollution Research Center version 99 (SAPRC-99) chemical mechanism (Carter, 2000) and the fifth-generation modal CMAQ aerosol module (Foley et al., 2010) are used. The Yamartino scheme (Yamartino, 1993) for advection and the Asymmetric Convective Model version 2 (ACM2) vertical diffusion scheme (Pleim, 2007) are adopted. The ACM cloud processor using the ACM methodology to compute convective mixing is used (Foley et al., 2010).

The gridded and speciated hourly anthropogenic emission data for South Korea are prepared using the Sparse Matrix Operator Kernel Emissions (SMOKE) system (Houyoux et al., 2000). Following Moon et al. (2006), an emission inventory is developed under the 2007 Clean Air Policy Support System of South Korea. The detailed methods for the spatial 
and temporal allocations of anthropogenic emissions for various source categories are described in Kim et al. (2008). In the present study, the gridded and speciated hourly anthropogenic emission data are derived from the emission inventory in 2007. Among the anthropogenic emission data, the $\mathrm{NO}_{\mathrm{x}}$ and VOC emission data are updated. The amounts of $\mathrm{NO}_{\mathrm{x}}$ (VOC) emitted are adjusted according to the ratio of the total annual emissions of $\mathrm{NO}_{\mathrm{x}}(\mathrm{VOC})$ in 2008 to those in 2007 because the only total annual emissions of $\mathrm{NO}_{\mathrm{x}}$ (VOC) in 2008 are available at present. As compared with the total annual emissions in 2007, the total annual emissions of $\mathrm{NO}_{\mathrm{x}}$ (VOC) in 2008 are reduced by $37 \%(12 \%)$ in Seoul. The total annual emissions of $\mathrm{NO}_{\mathrm{x}}, \mathrm{VOC}, \mathrm{CO}$, and $\mathrm{SO}_{\mathrm{x}}$ in Seoul, which are used in the present study, are given in Fig. S1 (Supplement). To prepare biogenic VOC (BVOC) emissions, the Model of Emissions of Gases and Aerosols from Nature (MEGAN) (Guenther et al., 2006) is used. As examples, the $\mathrm{NO}_{\mathrm{x}}$ and isoprene emission rates are given in Fig. 1c, $\mathrm{d}$, respectively. In the study area, the $\mathrm{NO}_{\mathrm{x}}$ emission rate is very high, particularly in the region near the city center and in the southwestern region of Seoul. That is, the urban area is characterized by a $\mathrm{NO}_{\mathrm{x}}$-rich area. Note that the emission rate shown in Fig. 1c is the rate at 15:00 LT on a weekday (Thursday). There are large forest areas near Seoul (Fig. 1b), and a significant amount of isoprene can be correspondingly emitted from the forest areas (Fig. 1d). On 24 June 2010, the maximum air temperature and the maximum hourly averaged global solar radiation observed at Seoul Meteorological Observatory were $30.8{ }^{\circ} \mathrm{C}$ and $839 \mathrm{~W} \mathrm{~m}^{-2}$, respectively. Because the air temperature was high and solar radiation was strong, the isoprene emission rate is estimated to be high.

To examine the impacts of urban land-surface forcing on air quality, an additional simulation is performed whose meteorological input is provided by the output of the additional WRF simulation in which the urban LULC is replaced with the cropland LULC (hereafter, NO-URBAN simulation). In this simulation, both the anthropogenic and biogenic emissions are set to be identical to those in the baseline simulation (hereafter, URBAN simulation).

\subsection{Process analysis}

The process analysis tool implemented in the CMAQ modeling system is used in this study. It comprises the integrated process rate (IPR) and integrated reaction rate (IRR) analyses. The IPR analysis quantifies the contributions of individual physical/chemical processes, such as advection, diffusion, deposition, and gas-phase chemistry processes, to changes in pollutant concentrations. The details of the analysis method are introduced by Jeffries and Tonnesen (1994), and the details of the way it is implemented in the CMAQ modeling system are given in Gipson (1999). Note that in the present study the horizontal and vertical advection processes are integrated into the total advection process (TADV) and that the horizontal and vertical diffusion processes are integrated into the total diffusion process (TDIF). The IRR analysis has been developed to provide quantitative information on individual chemical transformations (Jeffries and Tonnesen, 1994; Gipson, 1999). In the present study, several chemical reactions are grouped together to calculate the hydroxyl radical $(\mathrm{OH})$ chain length. The $\mathrm{OH}$ chain length is the number of times that $\mathrm{OH}$ goes through the $\mathrm{RO}_{\mathrm{x}}(=\mathrm{OH}$ $+\mathrm{HO}_{2}+\mathrm{RO}_{2}+\mathrm{RO}$ ) cycle before a termination reaction (Sheehy et al., 2010). It provides a measure of the overall efficiency of a gas-phase chemical mechanism in converting $\mathrm{NO}$ to $\mathrm{NO}_{2}$ for $\mathrm{O}_{3}$ formation in the atmosphere (Zhang et al., 2009). In the present study, the $\mathrm{OH}$ chain length is calculated based on the calculation method used in Mao et al. (2010). The IPR and IRR analyses are applied to the atmospheric boundary layer (ABL), and hourly outputs of the IPR/IRR analysis are used.

\section{Ozone episode}

A high $\mathrm{O}_{3}$ episode that occurred on 24 June 2010 is chosen in this study. As reported in Ryu and Baik (2012), the weather condition during the episode was characterized by weak synoptic wind, high temperature, and clear sky under a highpressure system. The wind speed observed at the $850 \mathrm{hPa}$ level in the daytime was lower than $4 \mathrm{~m} \mathrm{~s}^{-1}$. Under favorable weather conditions, several local circulations such as urbanbreeze, valley-breeze, and sea-breeze circulations developed in the daytime. The weak synoptic-wind condition is particularly important for the development of relatively strong urban-breeze circulation. The weather condition during the episode was also conducive to elevated $\mathrm{O}_{3}$ levels in conjunction with increased BVOC emissions. On 24 June 2010, high $\mathrm{O}_{3}$ concentrations, which exceed the Korean air quality standard of $100 \mathrm{ppb}$ (1-h average), were recorded in the Seoul metropolitan area. Note that the weather on the previous day (i.e. 23 June 2010) was also hot and clear under the highpressure system.

\section{Results and discussion}

\subsection{Model validation}

Simulated $\mathrm{O}_{3}$ concentrations are validated against observations (Figs. 2 and 3). Figure 2a shows the diurnal variations of observed $\mathrm{O}_{3}$ concentrations at air quality monitoring sites (marked by white circles in Fig. 1b) and range of simulated $\mathrm{O}_{3}$ concentration at the lowest model level at the corresponding locations. Note that all the analyses in this study are performed using simulation data in the innermost domain. The air quality monitoring sites corresponding to the urban LULC are adopted for the validation. The model adequately reproduces the maxima and minima of $\mathrm{O}_{3}$ concentration. Although the model overestimates $\mathrm{O}_{3}$ concentrations in the late afternoon and in the evening, the model captures the 
(a)

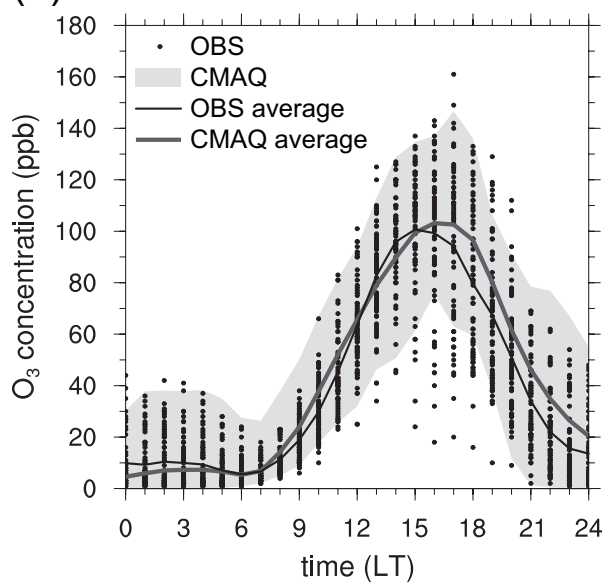

(b)

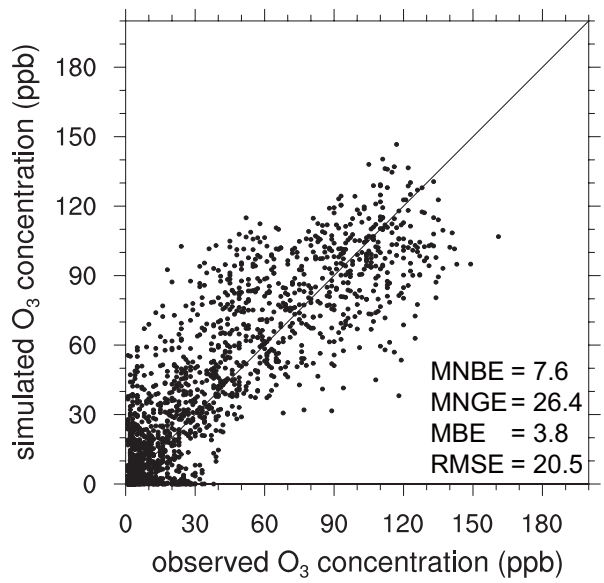

Fig. 2. (a) Diurnal variations of observed and simulated nearsurface $\mathrm{O}_{3}$ concentrations on 24 June 2010. The dots indicate the observed $\mathrm{O}_{3}$ concentrations at air quality monitoring sites marked in Fig. 1 b, and shading indicates the range of simulated $\mathrm{O}_{3}$ concentration at the corresponding locations. The thin and thick lines represent average observed and simulated $\mathrm{O}_{3}$ concentrations, respectively. (b) Scatter diagram of observed $\mathrm{O}_{3}$ concentrations and simulated ones on 24 June 2010. The MNBE and MNGE refer to the mean normalized bias error and mean normalized gross error, respectively, and their units are \%. The MBE and RMSE refer to the mean bias error and root-mean-square error, respectively, and their units are ppb.

diurnal variation of $\mathrm{O}_{3}$ concentration on average. Figure $2 \mathrm{~b}$ shows a relation between the observed and simulated $\mathrm{O}_{3}$ concentrations and performance statistics. The observed and simulated $\mathrm{O}_{3}$ concentrations are well correlated with each other. Following Lei et al. (2007) and Khiem et al. (2010), the mean normalized bias error (MNBE) and mean normalized gross error (MNGE) with observed $\mathrm{O}_{3}$ concentrations above a 40-ppb threshold are calculated. The MNBE and MNGE are $7.6 \%$ and $26.4 \%$, respectively, and satisfy the performance criteria recommended by the US Environmental Protection Agency (USEPA): MNBE is within $\pm 15 \%$ and
MNGE is less than or equal to $35 \%$ (USEPA, 1991). The mean bias error (MBE) is $3.8 \mathrm{ppb}$, and the root-mean-square error (RMSE) is $20.5 \mathrm{ppb}$. Overall, the model performs well in simulating $\mathrm{O}_{3}$ concentration.

Figure $3 \mathrm{a}, \mathrm{c}$ shows the horizontal distributions of observed and simulated $\mathrm{O}_{3}$ and $\mathrm{NO}_{2}$ concentrations at 15:00 LT. The model underestimates $\mathrm{O}_{3}$ concentrations and overestimates $\mathrm{NO}_{2}$ concentrations in the regions where $\mathrm{NO}_{\mathrm{x}}$ emissions are high, such as in the city center. The measurement heights lower than the lowest model level could be responsible to some extent for the discrepancies, particularly for the pollutants exhibiting large concentration variations in the vertical direction near the surface. However, the high $\mathrm{O}_{3}$ and the relatively low $\mathrm{NO}_{2}$ concentrations in the northern and southern regions of Seoul are well reproduced. Although $\mathrm{O}_{3}$ concentrations are underestimated in the southwestern region of Seoul and in the southwestern region outside Seoul where the sea breeze prevails, the high $\mathrm{NO}_{2}$ concentrations in those regions are well captured by the model.

\subsection{Impacts of urban land-surface forcing on local meteorology}

To understand the impacts of urban land-surface forcing on local meteorology, results of the URBAN simulation are compared with those of the NO-URBAN simulation. Figure 4 displays the diurnal variations of air temperature at $2 \mathrm{~m}$ and ABL height averaged over the urban analysis area indicated by the rectangle in Fig. 1b. The urban analysis area that covers Seoul is chosen because urban-breeze circulation develops well and interacts strongly with other local circulations in this area. Note that only the grids corresponding to the urban LULC in the urban analysis area are used for all related analyses. Because of the distinctive urban-surface characteristics, such as low surface moisture availability, large thermal inertia, and low albedo, the air temperature in urban areas can be higher by several degrees than that in surrounding rural areas. During the episode, the air temperature is higher in the URBAN simulation than in the NOURBAN simulation (Fig. 4a). Under fair weather conditions, the nighttime air temperature in the URBAN simulation is $4-6{ }^{\circ} \mathrm{C}$ higher than that in the NO-URBAN simulation. Because of the warmer and less-stabilized air in the urban area, the ABL height in the URBAN simulation remains higher in the nighttime (Fig. 4b). After sunrise ( 05:10 LT), the ABL grows deeper in the URBAN simulation and hence the difference in ABL height between the two simulations becomes larger. In the afternoon, the difference in air temperature between the two simulations increases (e.g. $0.3^{\circ} \mathrm{C}$ at $11: 00 \mathrm{LT}$, $0.5^{\circ} \mathrm{C}$ at 13:00 LT, and $0.9^{\circ} \mathrm{C}$ at 15:00 LT) and the difference in ABL height increases correspondingly. The difference in ABL height becomes very large in the late afternoon and in the early evening, i.e. around sunset. For example, the difference in ABL height is $\sim 900 \mathrm{~m}$ at 18:00 LT. Because of the large thermal inertia of the urban surface, the urban surface 
(a) $\mathrm{O}_{3}$ URBAN at $1500 \mathrm{LT}$

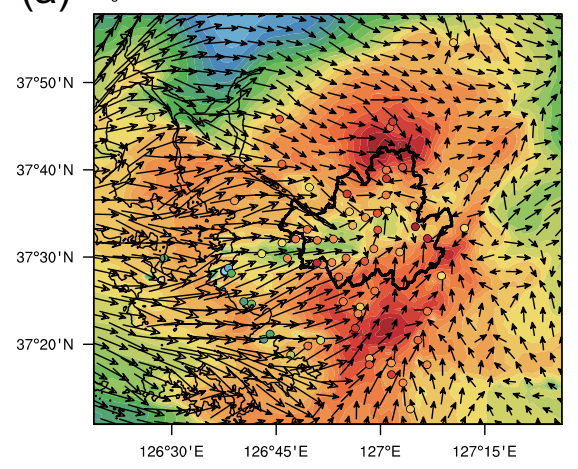

(c) $\mathrm{NO}_{2}$ URBAN at $1500 \mathrm{LT}$

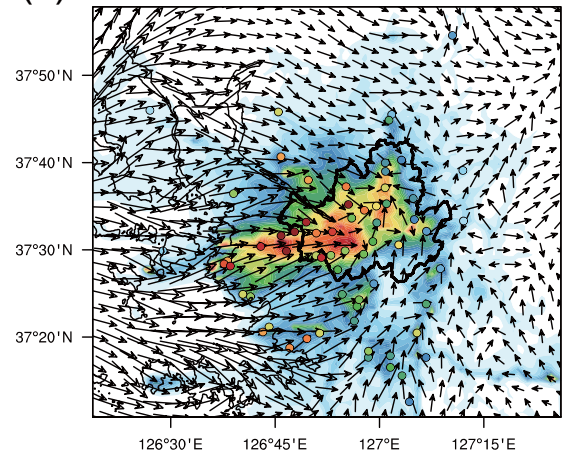

(e) $\Delta \mathrm{O}_{3}$ at $1500 \mathrm{LT}$

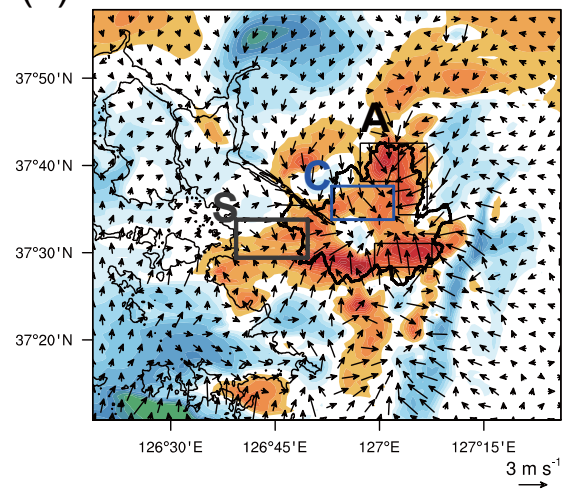

(b) $\mathrm{O}_{3}$ NO-URBAN at $1500 \mathrm{LT}$

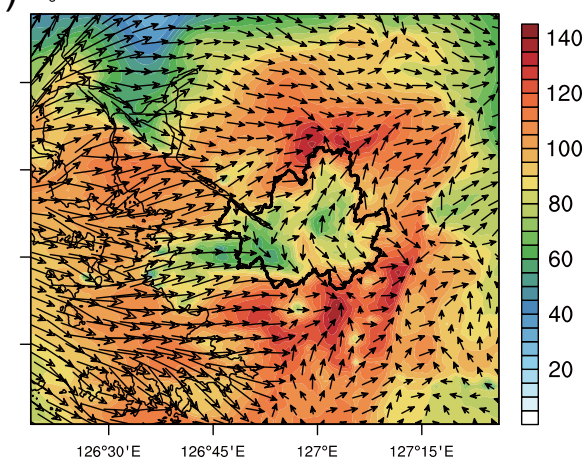

(d) $\mathrm{NO}_{2}$ NO-URBAN at $1500 \mathrm{LT}$

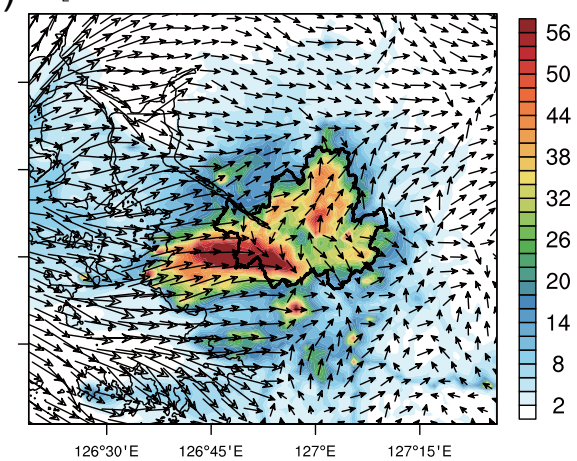

(f) $\Delta \mathrm{NO}_{2}$ at $1500 \mathrm{LT}$

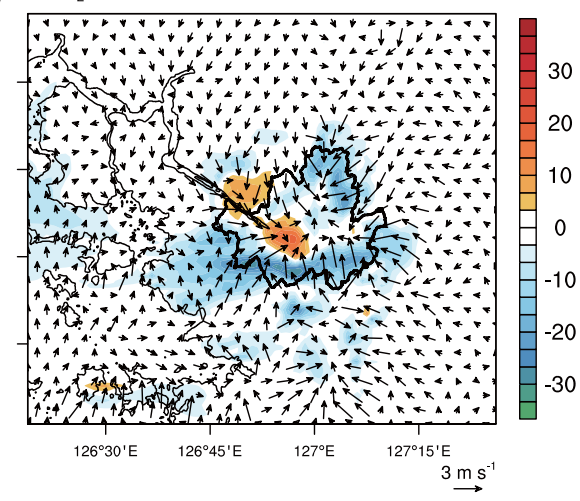

Fig. 3. Horizontal distributions of (a) $\mathrm{O}_{3}$ and (c) $\mathrm{NO}_{2}$ concentrations and horizontal wind at the lowest model level at 15:00 LT in the URBAN simulation. The circles in (a) and (c) show the observed $\mathrm{O}_{3}$ and $\mathrm{NO}_{2}$ concentrations, respectively. (b) and (d) are the same as (a) and (c), respectively, but for the NO-URBAN simulation. (e) Differences in $\mathrm{O}_{3}$ concentration and horizontal wind between the two simulations (URBAN minus NO-URBAN). (f) is the same as (e) but for $\mathrm{NO}_{2}$. The concentration units are ppb. Region A, region C, and region $\mathrm{S}$ are marked in (e) by the three rectangles with a thin black line, with a thick blue line, and with a thick grey line, respectively.

cools off more slowly than the cropland does, thus maintaining the deep urban boundary layer.

Not only the ABL but also the wind in the urban area is significantly modified by urban land-surface forcing. Here, based on the analysis results reported in Ryu and Baik (2012), the wind induced and/or modified by urban landsurface forcing is briefly mentioned. In both the URBAN and NO-URBAN simulations, the valley-breeze circulation prevails in the mid- to late morning ( 08:00-11:00 LT). In the afternoon, on the other hand, the prevailing local circu- lation in the URBAN simulation turns to the urban-breeze circulation induced by the daytime UHI. In the afternoon, the valley-breeze circulation weakens because its direction is opposite to the direction of the urban-breeze circulation. As an example, the horizontal wind field in the afternoon is illustrated in Fig. 3a. It is seen that the strong convergent flow that forms part of the urban-breeze circulation is predominant in the northern and southeastern regions of Seoul that are not yet influenced by the sea breeze. In contrast, in the 
(a)

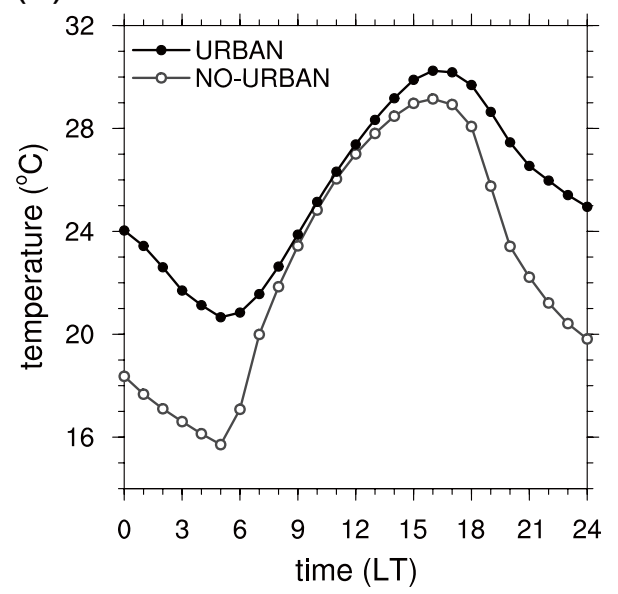

(b)

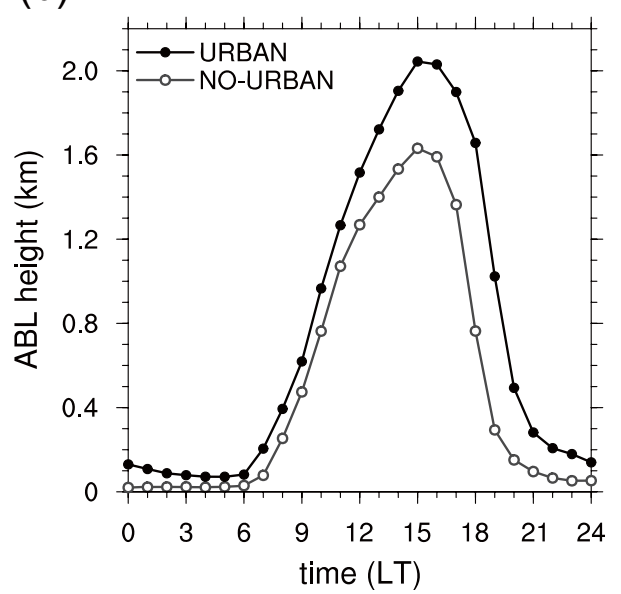

Fig. 4. Diurnal variations of (a) air temperature at $2 \mathrm{~m}$ and (b) atmospheric boundary layer (ABL) height averaged over the urban analysis area in the URBAN and NO-URBAN simulations.

NO-URBAN simulation, the valley-breeze circulation prevails in the afternoon (Fig. 3b).

Under the influence of the high-pressure system, the sea/land-breeze circulations prevail on the episode day and the previous day. In the nighttime and in the early morning, the land breeze dominates in the study area. The sea breeze starts to develop in the mid-morning on 24 June 2010 and penetrates inland. At 15:00 LT, the strong westerly sea breeze in both simulations is apparent in Fig. 3a, b. At this time, the sea breeze prevails in the western region outside Seoul and in the southwestern region of Seoul (e.g. in region S marked by the rectangle with a thick grey line in Fig. 3e). Furthermore, owing to urban land-surface forcing, the sea breeze penetrates further inland and is intensified in the URBAN simulation. The location of the sea-breeze front at this time in the two simulations is given in Sect. 4.5.

\subsection{Impacts of urban-modified boundary layer on air quality}

The ABL height significantly influences pollutant concentrations, and hence the urban-modified ABL can have considerable impacts on pollutant concentrations in urban areas. Figure 5 shows the diurnal variations of near-surface concentrations of $\mathrm{O}_{3}, \mathrm{NO}_{\mathrm{x}}, \mathrm{O}_{\mathrm{x}}\left(=\mathrm{O}_{3}+\mathrm{NO}_{2}\right.$ in this study), and $\mathrm{CO}$ averaged over the urban analysis area in the URBAN and NO-URBAN simulations. Note that the near-surface concentrations are referred to as the concentrations at the lowest model level. On average, $\mathrm{O}_{3}$ concentration is $16 \mathrm{ppb}$ higher in the nighttime (from 00:00 to 05:00 LT and from 20:00 to 24:00 LT) and is $13 \mathrm{ppb}$ higher in the daytime (from 06:00 to 19:00 LT) in the URBAN simulation than in the NO-URBAN simulation. In the nighttime, the higher $\mathrm{O}_{3}$ concentration is primarily due to the reduced $\mathrm{O}_{3}$ destruction by $\mathrm{NO}$ in the deeper urban boundary layer. Note that in this case study the urban area is found to be in a $\mathrm{NO}_{\mathrm{x}}$-saturated (or VOClimited) regime by systematically examining the sensitivities of $\mathrm{O}_{3}$ to its precursor emissions (not shown). In the deep urban boundary layer, the primary pollutants such as $\mathrm{NO}_{\mathrm{x}}$ and $\mathrm{CO}$ are diluted and hence their near-surface concentrations become lower (Fig. 5b, d), as demonstrated by Sarrat et al. (2006). The reduced $\mathrm{O}_{3}$ destruction by $\mathrm{NO}$ is particularly prominent in the evening when simultaneously the urban boundary layer remains deep and $\mathrm{NO}_{\mathrm{x}}$ emissions are high in conjunction with rush-hour traffic. In the evening, the differences in $\mathrm{NO}_{\mathrm{x}}$ and $\mathrm{CO}$ concentrations between the two simulations are large. The lower $\mathrm{O}_{\mathrm{x}}$ level in the evening (and also at night and in the morning) is therefore due to the lower $\mathrm{NO}_{2}$ concentration in the URBAN simulation. In the shallow ABL in the NO-URBAN simulation, $\mathrm{O}_{3}$ destruction by $\mathrm{NO}$ is enhanced and, consequently, $\mathrm{O}_{3}$ concentration decreases rapidly over time as the ABL height decreases, particularly in the evening. In the morning, the differences in $\mathrm{NO}_{\mathrm{x}}$ and $\mathrm{CO}$ concentrations between the two simulations are also large, but the difference in $\mathrm{O}_{3}$ concentration is rather small. In the morning, the near-surface $\mathrm{O}_{3}$ concentration increases significantly in both simulations. One of the reasons for the increase is the mixing bringing down $\mathrm{O}_{3}$ from the previous day's reservoir aloft (residual layer). The downward vertical mixing of $\mathrm{O}_{3}$ from the residual layer dominates in both simulations, leading to the small difference in $\mathrm{O}_{3}$ concentration between the two simulations, so the effect of the reduced $\mathrm{O}_{3}$ destruction by $\mathrm{NO}$ in the URBAN simulation seems to be insignificant. In addition to the downward vertical mixing of $\mathrm{O}_{3}$, the horizontal advection of $\mathrm{O}_{3}$ and the chemical production of $\mathrm{O}_{3}$ contribute to the increase in $\mathrm{O}_{3}$ concentration in both simulations. In the afternoon, the difference in $\mathrm{O}_{3}$ concentration between the two simulations becomes large. For example, $\mathrm{O}_{3}$ concentration is $6 \mathrm{ppb}$ higher at 13:00 LT and is $17 \mathrm{ppb}$ higher at 16:00 LT in the URBAN simulation than in the NO-URBAN simulation. Apart from the reduced $\mathrm{O}_{3}$ destruction by $\mathrm{NO}$, the chemical production of $\mathrm{O}_{3}$ is enhanced 
(a)

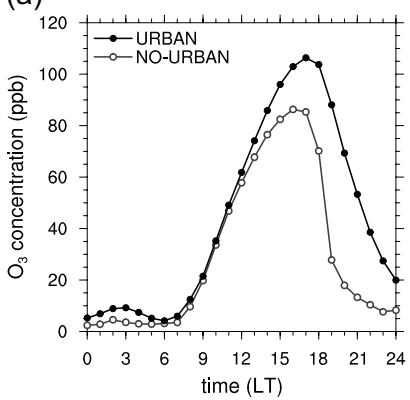

(c)

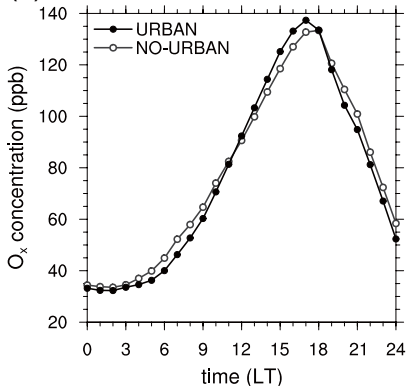

(b)

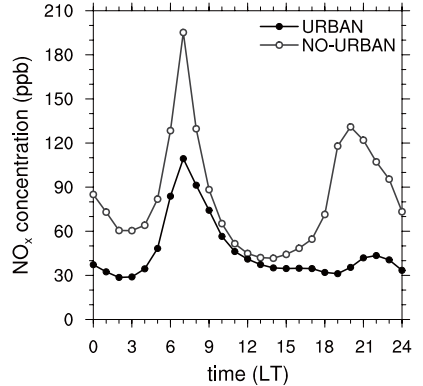

(d)

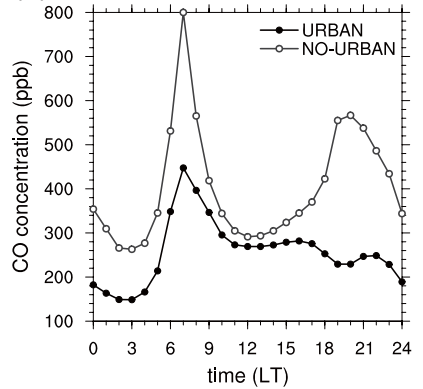

Fig. 5. Diurnal variations of near-surface concentrations of (a) $\mathrm{O}_{3}$, (b) $\mathrm{NO}_{\mathrm{x}}$, (c) $\mathrm{O}_{\mathrm{x}}\left(=\mathrm{O}_{3}+\mathrm{NO}_{2}\right)$, and (d) $\mathrm{CO}$ averaged over the urban analysis area in the URBAN and NO-URBAN simulations.

in the afternoon, as can be inferred from the higher $\mathrm{O}_{\mathrm{x}}$ level in the URBAN simulation.

To evaluate the contributions of individual physical/chemical processes to changes in $\mathrm{O}_{3}$ concentration, an IPR analysis is performed. Figure 6 shows the ABL-averaged contributions of individual physical/chemical processes for the period from 12:00 to 16:00 LT, when the chemical production of $\mathrm{O}_{3}$ is found to be large. Based on the IPR analysis, the enhanced chemical production of $\mathrm{O}_{3}$ in the URBAN simulation is confirmed. The contribution of the advection process is also larger in the URBAN simulation. This implies that the advection of $\mathrm{O}_{3}$ by the wind induced and/or modified by urban land-surface forcing also contributes to the elevated $\mathrm{O}_{3}$ levels. While $\mathrm{O}_{3}$ in the residual layer is brought into the $\mathrm{ABL}$ in the morning when the $\mathrm{ABL}$ grows rapidly, $\mathrm{O}_{3}$ is partially vented out of the ABL into the free atmosphere in the afternoon by intense upward motion (see the positive contribution of the advection process above the ABL in Fig. 7b) and vigorous mixing (negative contribution of the diffusion process in Fig. 6) in the URBAN simulation. The upward transport of $\mathrm{O}_{3}$ into the free atmosphere can lead to an increased lifetime of $\mathrm{O}_{3}$ there (Henne et al., 2004) and possibly contribute to the long-range transport of $\mathrm{O}_{3}$. A relatively large difference in the contribution of the dry deposition process is found in Fig. 6. The daytime-averaged dry deposition velocity averaged over the urban analysis area in the NOURBAN simulation is almost 2 times that in the URBAN simulation (not shown). This results from the change in landsurface characteristics, e.g. from the lesser vegetated surface

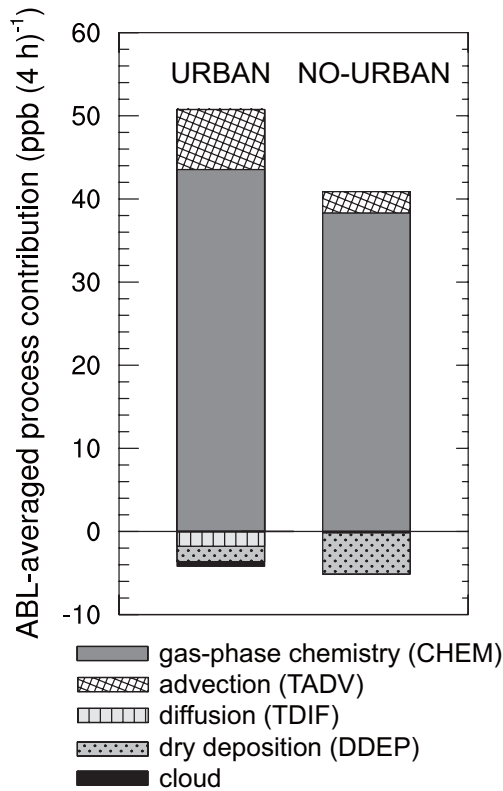

Fig. 6. Time-integrated contributions of individual processes averaged in the ABL over the urban analysis area for the period from 12:00 to 16:00 LT in the URBAN and NO-URBAN simulations.

(urban surface) to the highly vegetated surface (cropland). As the urban surface is altered by the cropland, the stomatal resistance, mesophyl resistance, lower canopy resistance, and other resistances are correspondingly altered. However, the effect of the dry deposition process is confined to the lowest layer, so the difference in the contribution of the dry deposition process in the ABL between the two simulations is small relative to that of the chemical or advection process. In the URBAN simulation, $\mathrm{O}_{3}$ concentration slightly decreases by the cloud process, which is likely due to the intense upward motion in the urban area. In the cloud process, the effects of clouds on photolysis rates, convective and nonconvective mixing and scavenging by clouds, aqueous-phase chemistry, and wet deposition are included (Zhang et al., 2009).

Figure 7 shows the vertical profiles of $\mathrm{O}_{3}$ and $\mathrm{O}_{x}$ concentrations and contributions of individual processes to $\mathrm{O}_{3}$ and $\mathrm{O}_{\mathrm{x}}$ concentrations averaged over the urban analysis area for the period from 12:00 to 16:00 LT. The $\mathrm{O}_{3}$ and $\mathrm{O}_{\mathrm{x}}$ concentrations in the ABL are higher in the URBAN simulation than in the NO-URBAN simulation (Fig. 7a, c). The differences in the contribution of the chemical process to $\mathrm{O}_{3}$ and $\mathrm{O}_{\mathrm{x}}$ concentrations between the two simulations are large in the surface layer and in the upper ABL. In the URBAN simulation, the chemical loss of $\mathrm{O}_{3}$ is reduced in the surface layer (Fig. 7b) and the chemical production of $\mathrm{O}_{\mathrm{x}}$ is enhanced there (Fig. 7d). In the upper ABL, the enhanced chemical production of $\mathrm{O}_{3}$ in the URBAN simulation results from the upward transport of $\mathrm{O}_{3}$ precursors by both enhanced upward motion and turbulence in the urban boundary layer. Considering the larger contributions of the advection and diffusion 
(a)

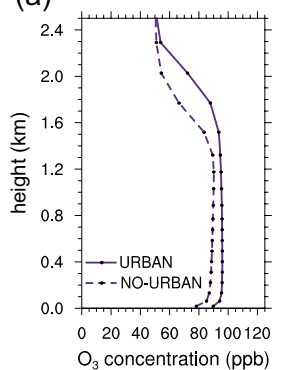

(c)

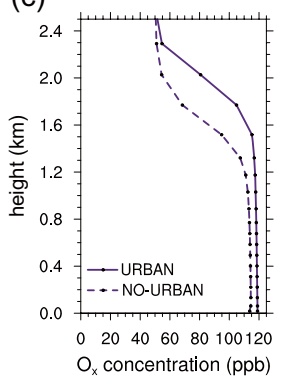

(b)

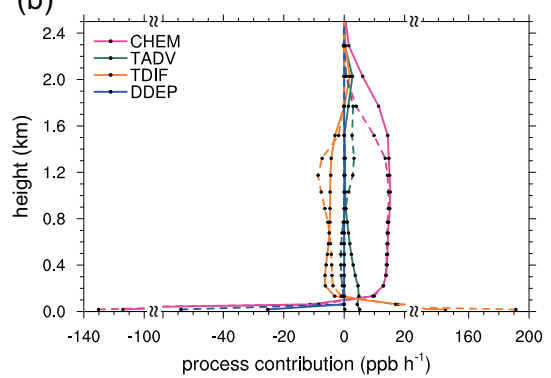

(d)

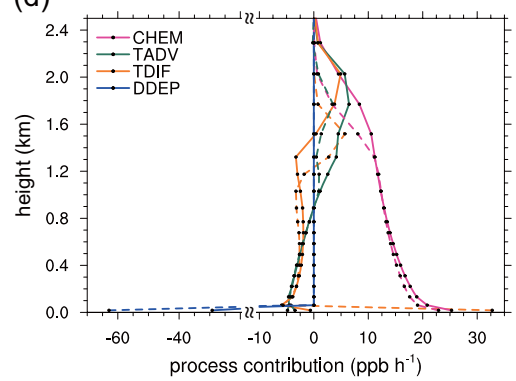

Fig. 7. 4-h-average vertical profiles of (a) $\mathrm{O}_{3}$ and (c) $\mathrm{O}_{x}$ concentrations, and contributions of individual processes to (b) $\mathrm{O}_{3}$ concentration and (d) $\mathrm{O}_{\mathrm{x}}$ concentration averaged over the urban analysis area for the period from 12:00 to 16:00 LT. Note that the solid (dashed) lines in (b) and (d) indicate the results of the URBAN (NO-URBAN) simulation. The same abbreviations for the processes as those in Fig. 6 are used.

processes to $\mathrm{O}_{\mathrm{x}}$ concentration in the upper ABL (Fig. 7d) relative to those to $\mathrm{O}_{3}$ concentration there (Fig. $7 \mathrm{~b}$ ), $\mathrm{NO}_{2}$ is transported to the upper ABL by the advection and diffusion processes. Other $\mathrm{O}_{3}$ precursors such as VOCs are also transported upward (not shown). So, the chemical production of $\mathrm{O}_{\mathrm{x}}$ as well as the chemical production of $\mathrm{O}_{3}$ can be enhanced in the upper ABL in the URBAN simulation. In addition to the urban-modified boundary layer, the urbaninduced local circulation contributes to the enhanced chemical production of $\mathrm{O}_{3}$ in the URBAN simulation. The impacts of urban-induced/-modified local circulation are described in detail in Sect. 4.4.

In the URBAN simulation, the advection process contributes to the increase in $\mathrm{O}_{3}$ concentration in the lower $\mathrm{ABL}$ (Fig. 7b). In the NO-URBAN simulation, the advection process makes a negligible contribution in the lower ABL but a positive contribution in the upper ABL. The different contributions of the advection process between the two simulations are closely related to the different prevailing local circulations: urban-breeze circulation versus valley-breeze circulation. The detailed analysis results are presented in the following section.

The near-surface removal of $\mathrm{O}_{3}$ by dry deposition is less in the URBAN simulation than in the NO-URBAN simulation, which can contribute to the near-surface $\mathrm{O}_{3}$ concentration in the URBAN simulation. In the NO-URBAN simulation,

the large decrease in $\mathrm{O}_{3}$ concentration by dry deposition and chemical processes in the surface layer is compensated by the downward vertical mixing of $\mathrm{O}_{3}$ from the upper layers.

\subsection{Impacts of urban-induced/-modified local circulation on air quality}

As mentioned in Sect. 4.2, the prevailing local circulation in the mid- to late morning in both simulations is the valleybreeze circulation. As the sensible heat from the urban surface increases and accordingly the air temperature increases over time in the URBAN simulation, the valley-breeze circulation weakens and urban-breeze circulation starts to develop in the late morning/early afternoon. As an example, Fig. 8 shows the vertical cross sections of $\mathrm{NO}_{2}$ concentration, the results of the IPR analysis for $\mathrm{NO}_{2}$ and $\mathrm{O}_{3}$ concentrations, and wind along the line $\mathrm{M}-\mathrm{N}$ (depicted in Fig. 1d) at 11:00 LT, when the valley-breeze circulation develops in both simulations. The cross section along the line $\mathrm{M}-\mathrm{N}$ is chosen to show representative examples of the valley-breeze and urban-breeze circulations. The valley-breeze circulation is characterized by upslope flow along the mountain slope and return flow in the upper ABL. In the URBAN simulation, it is found that the intensity of upslope flow is weaker than that in the NO-URBAN simulation owing to the higher air temperature in the urban valley (UHI effect). At the same time, the wind field in the URBAN simulation shows an onset of an urban-breeze circulation near the lower part of the mountain $\left(\sim 37^{\circ} 27^{\prime} \mathrm{N}\right)$. In both simulations, $\mathrm{NO}_{2}$ is advected over the mountain crest following the upslope wind, thus showing positive contributions of the advection process there. Because of the smaller amount of $\mathrm{NO}_{2}$ that is advected by the weaker upslope wind, the contribution of the chemical process to $\mathrm{O}_{3}$ concentration over the mountain is smaller in the URBAN simulation than in the NO-URBAN simulation. In both simulations, in addition to the advection of $\mathrm{NO}_{2}$ by the valley-breeze circulation, the enhanced chemical production of $\mathrm{O}_{3}$ over the mountain in comparison with the chemical production of $\mathrm{O}_{3}$ in the urban area (cropland area) is due to very low $\mathrm{NO}_{\mathrm{x}}$ emissions and high $\mathrm{BVOC}$ emissions. The $\mathrm{O}_{3}$ concentration over the mountain is of course higher than that in the urban area (cropland area) (not shown). The advection of $\mathrm{NO}_{2}$ in the mid- to late morning also appears over other mountains in the study area.

In the afternoon, the prevailing local circulations in the two simulations are different from each other (for example, see Fig. 3a, b). As shown in the area-averaged concentration (Fig. 5), $\mathrm{O}_{3}$ concentration in the urban analysis area is generally higher in the URBAN simulation than in the NOURBAN simulation (compare Fig. 3a with Fig. 3b). In particular, the difference in $\mathrm{O}_{3}$ concentration is large in the regions near the city boundaries (Fig. 3e). Likewise, the difference in $\mathrm{NO}_{2}$ concentration is large in the regions near the city boundaries (Fig. 3f). 
(a)

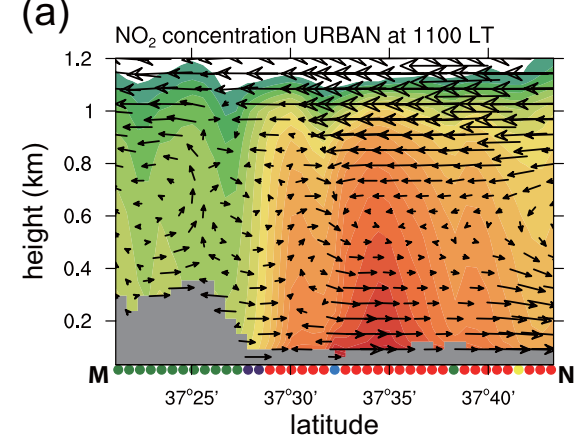

(c)

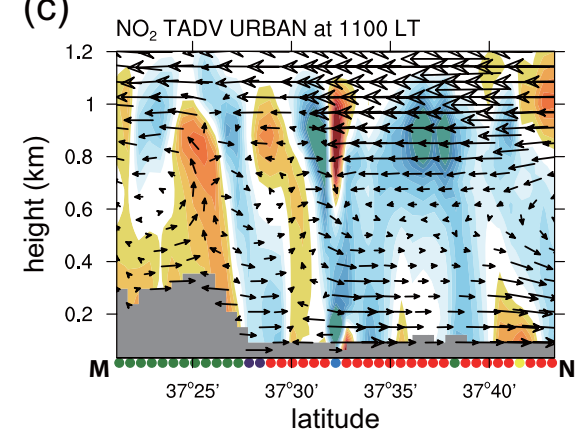

(e)

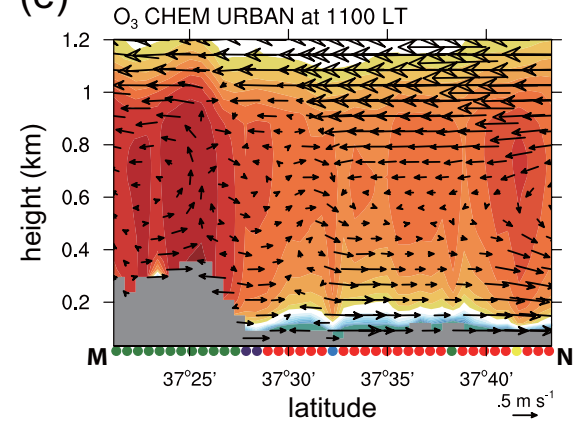

(b)

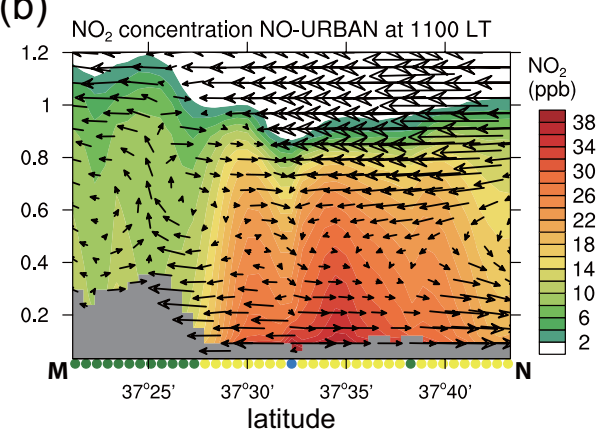

(d)

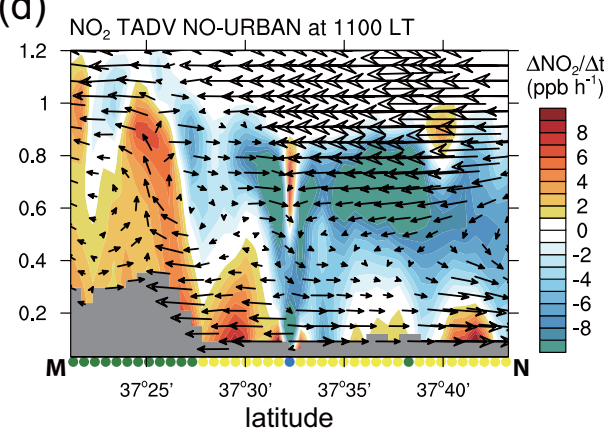

(f)

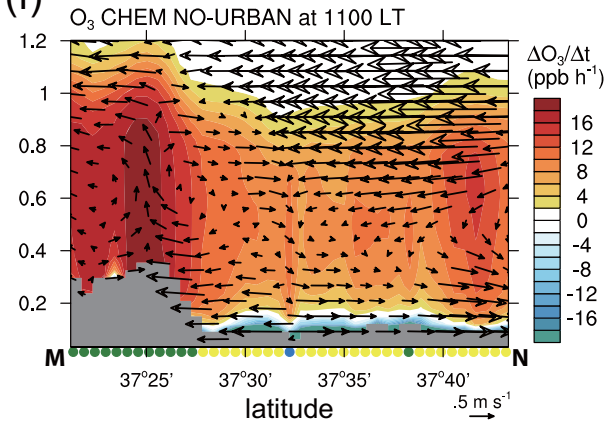

Fig. 8. Vertical cross sections of (a) $\mathrm{NO}_{2}$ concentration, (c) contribution of the advection process to $\mathrm{NO}_{2}$ concentration, (e) contribution of the chemical process to $\mathrm{O}_{3}$ concentration, and wind along the line $\mathrm{M}-\mathrm{N}$ in Fig. 1d at 11:00 LT in the URBAN simulation. (b), (d), and (f) are the same as (a), (c), and (e), respectively, but for the NO-URBAN simulation. The color of circles on the $\mathrm{x}$-axis corresponds to the color of the LULC in Fig. $1 b$.

In both simulations, the sea breeze brings $\mathrm{O}_{3}$-rich air onto land. The advection of $\mathrm{O}_{3}$ precursors by the land breeze in the nighttime and in the early morning results in the build-up of $\mathrm{O}_{3}$ over the Yellow Sea (not shown). The $\mathrm{O}_{3}$ concentration is high in the regions where the sea breeze prevails, except for the regions where $\mathrm{NO}_{\mathrm{x}}$ emissions are high (e.g. region S) (Fig. 3a, b). The $\mathrm{O}_{3}$ concentration in region $\mathrm{S}$ is higher in the URBAN simulation than in the NO-URBAN simulation (Fig. 3e). The detailed analysis results of the impacts of urban-modified sea breeze on ozone air quality are given in Sect. 4.5.

To get some insight into the reason for the elevated $\mathrm{O}_{3}$ levels in the presence of urban land-surface forcing, the contributions of the advection and chemical processes averaged in the lower $\mathrm{ABL}$ (from the surface to mid-ABL) are pre- sented in Fig. 9. In the lower ABL where the local circulations directly influence near-surface pollutant concentrations, $\mathrm{O}_{3}$ concentration in the regions near the city boundaries significantly increases in the URBAN simulation but decreases in the NO-URBAN simulation by the advection process (Fig. 9a, b). In the URBAN simulation, the $\mathrm{O}_{3}$-rich air is advected over the urban area from the surroundings following the urban-breeze circulation. On the other hand, in the NO-URBAN simulation, $\mathrm{O}_{3}$ is advected toward the surroundings by the valley-breeze circulation. Therefore, the difference in the contribution of the advection process to $\mathrm{O}_{3}$ concentration between the two simulations is large in the regions near the city boundaries (Fig. 9e). Comparing Fig. 9c with Fig. 9d, differences in the contribution of the chemical process are found between the two simulations (Fig. 9f). 
(a) Iower ABL-averaged TADV URBAN at 1500 LT

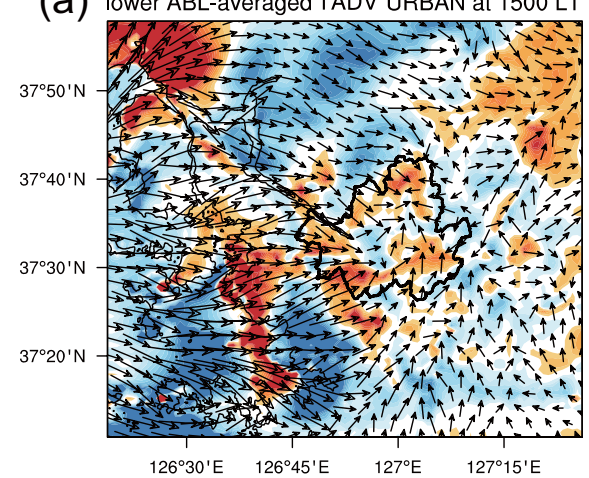

(c) Iower ABL-averaged CHEM URBAN at $1500 \mathrm{LT}$

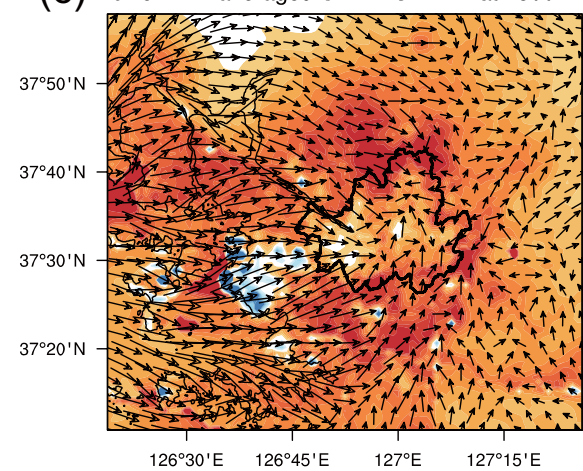

(e) $\triangle$ TADV at $1500 \mathrm{LT}$

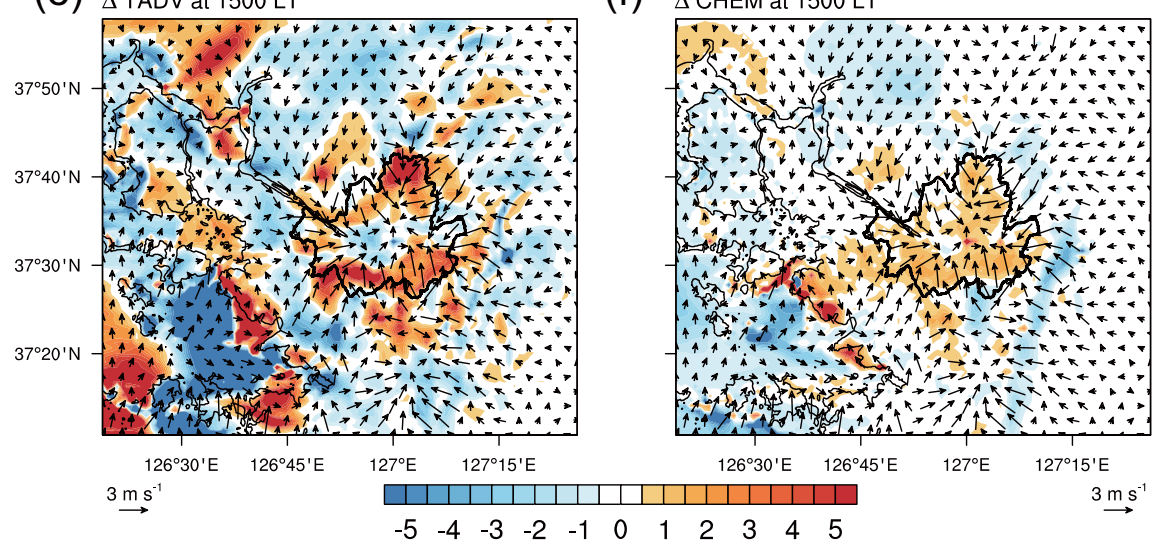

(b) Iower ABL-averaged TADV NO-URBAN at 1500 LT

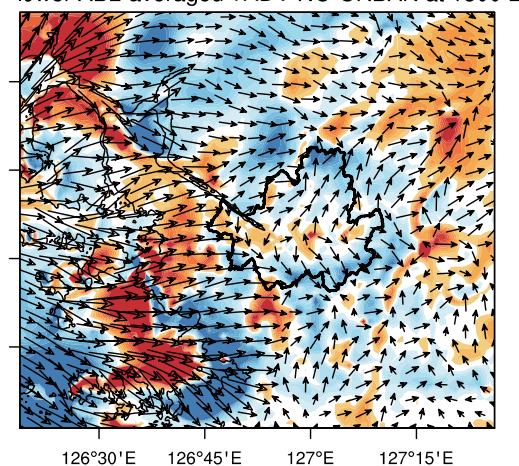

(d) lower ABL-averaged CHEM NO-URBAN at 1500 LT

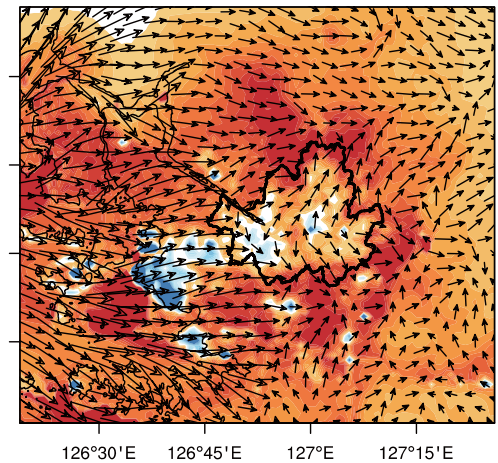

(f) $\triangle \mathrm{CHEM}$ at $1500 \mathrm{LT}$

Fig. 9. Horizontal distributions of column-averaged contributions of the (a) advection process and (c) chemical process to $\mathrm{O}_{3}$ concentration in the lower ABL at 15:00 LT in the URBAN simulation. (b) and (d) are the same as (a) and (c), respectively, but for the NO-URBAN simulation. (e) and (f) show the differences in the contributions of the advection and chemical processes between the two simulations, respectively. The units are $\mathrm{ppbh}^{-1}$. The horizontal winds are the winds at the lowest model level.

Figure 10 shows the vertical cross sections of $\mathrm{O}_{3}$ concentration, contributions of the advection and chemical processes, and wind along the line $\mathrm{M}-\mathrm{N}$ at 15:00 LT. In the URBAN simulation, the urban-breeze circulation develops in the urban area adjacent to the mountain. Another welldeveloped urban-breeze circulation is found in the northern region of the cross section $\left(\sim 37^{\circ} 40^{\prime} \mathrm{N}\right)$. It is clearly seen that following the convergent flow the $\mathrm{O}_{3}$-rich air is advected over the urban area from the surroundings (Fig. 10c), as seen in the horizontal distribution of the contribution of the ad- vection process (Fig. 9a). The $\mathrm{O}_{3}$-rich air over the mountain results from the supply of $\mathrm{NO}_{2}$ by the valley-breeze circulation in the mid- to late morning and from BVOC emissions from the forest area. As the prevailing local circulation in the afternoon turns to the urban-breeze circulation, $\mathrm{O}_{3}$ over the mountain is brought into the urban area. Thus, under the circumstances in which both anthropogenic and biogenic (natural) emissions play important roles in $\mathrm{O}_{3}$ formation, the urban-breeze circulation that prevails against the valleybreeze circulation can substantially contribute to elevated $\mathrm{O}_{3}$ 
(a)

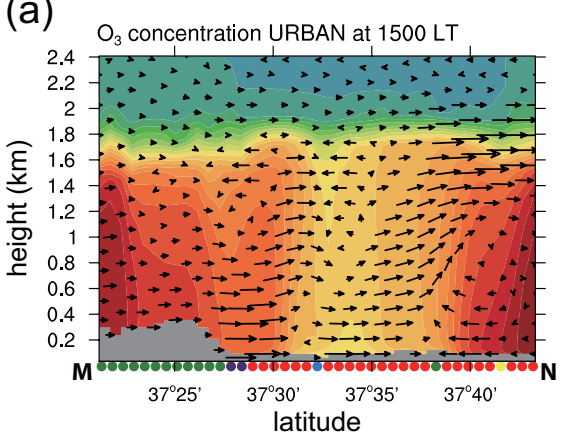

(c)

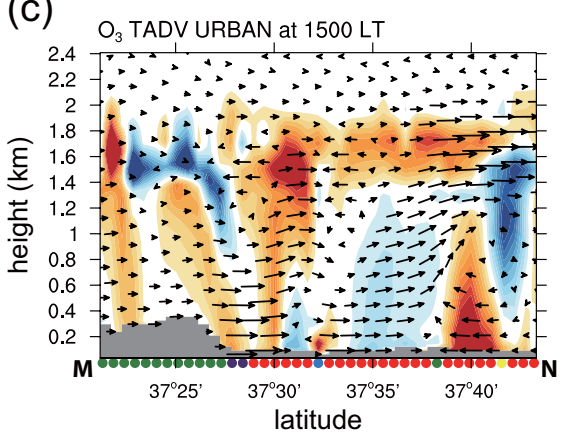

(e)

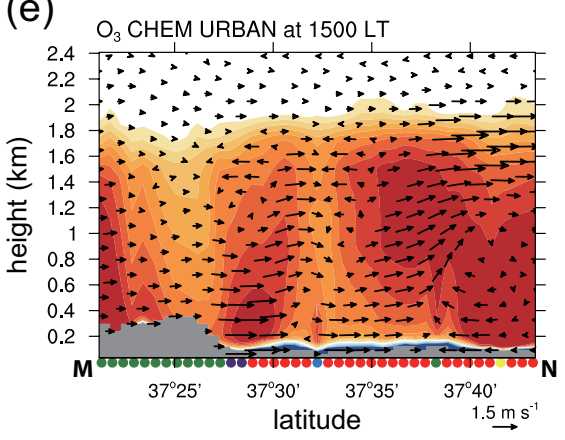

(b)

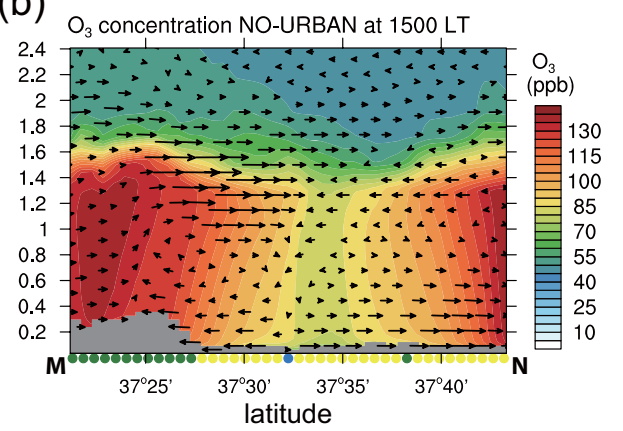

(d)

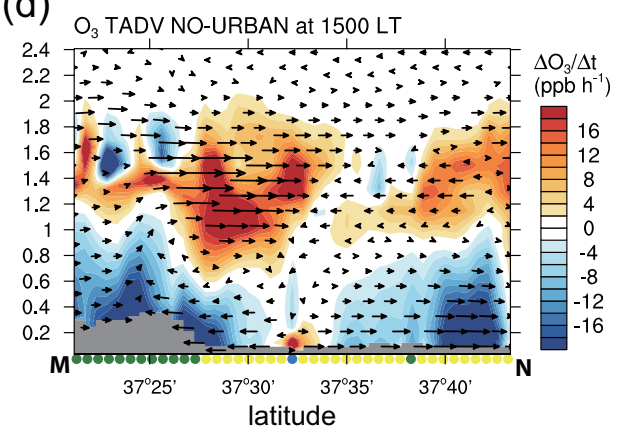

(f)

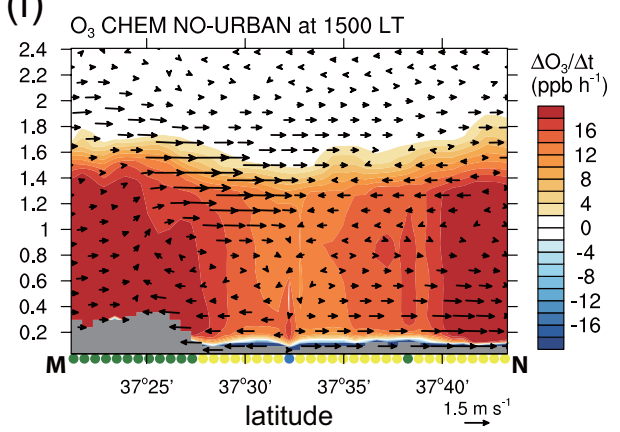

Fig. 10. Vertical cross sections of (a) $\mathrm{O}_{3}$ concentration, (c) contribution of the advection process, (e) contribution of the chemical process to $\mathrm{O}_{3}$ concentration, and wind along the line $\mathrm{M}-\mathrm{N}$ in Fig. 1d at 15:00 LT in the URBAN simulation. (b), (d), and (f) are the same as (a), (c), and (e), respectively, but for the NO-URBAN simulation. The color of circles on the x-axis corresponds to the color of the LULC in Fig. 1b.

levels in the urbanized basin area by recirculating pollutants. This implies that urban land-surface forcing can exacerbate air pollution problems in urban areas, particularly those adjacent to mountains.

In the NO-URBAN simulation, on the other hand, the valley-breeze circulations still prevail in the southern and northern regions of the cross section (see Figs. $8 \mathrm{~b}$ and 10b). Therefore, $\mathrm{O}_{3}$ is advected toward the surroundings in the lower ABL, showing negative contributions of the advection process there (Fig. 10d). However, the convergent flow toward the basin in the upper branch of the valley-breeze circulation brings the $\mathrm{O}_{3}$-rich air into the cropland area, thus showing positive contributions of the advection process in the upper ABL. This recirculation can contribute to an increase in near-surface $\mathrm{O}_{3}$ concentration. Ozone in the upper ABL diffuses downward, as can be inferred from the large negative contribution of the diffusion process in the upper ABL (Fig. 7b). In addition, $\mathrm{O}_{3}$ aloft can be mixed as the $\mathrm{ABL}$ in the basin grows over time. These results are consistent with the findings of previous studies of the impacts of valley-breeze circulation on air quality (e.g. Fast and Zhong, 1998). However, the recirculated $\mathrm{O}_{3}$ tends to stay in the upper ABL, exhibiting the relatively large vertical gradient of $\mathrm{O}_{3}$ concentration (Fig. 10b).

In the URBAN simulation, an interesting result is that the contribution of the chemical process is large in the regions where the urban breeze prevails (Fig. 10e). To understand the enhanced chemical production of $\mathrm{O}_{3}$ in these regions, an IRR analysis is performed (Fig. 11). Over the mountain and in the regions where the urban breeze prevails, the $\mathrm{OH}$ chain length is long (Fig. 11a). The long $\mathrm{OH}$ chain length in the air mass over the mountain is attributed 
(a)

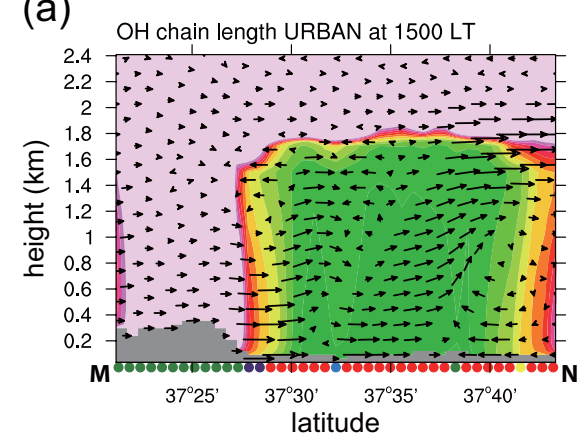

(c)

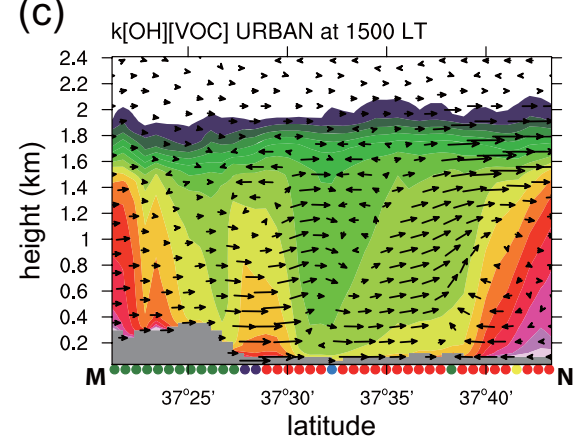

(e)

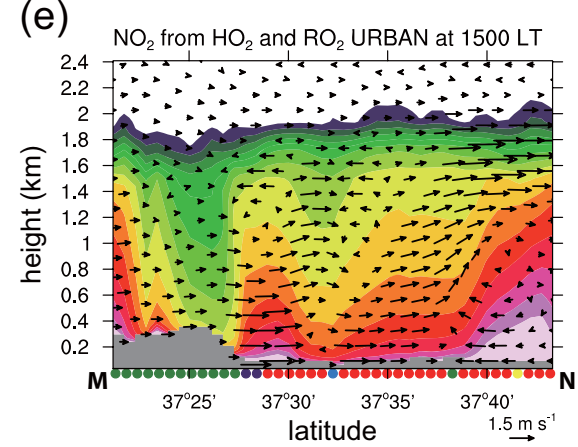

(b)

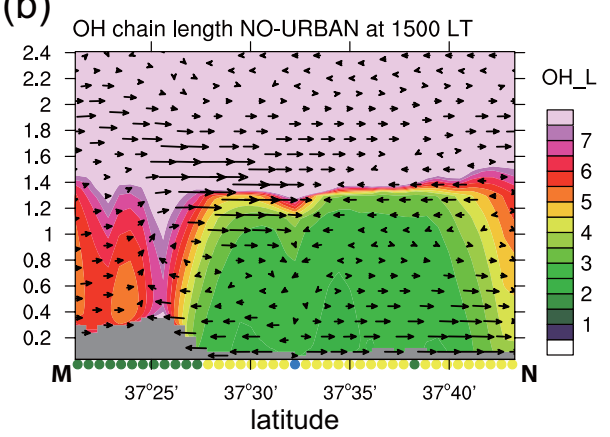

(d)

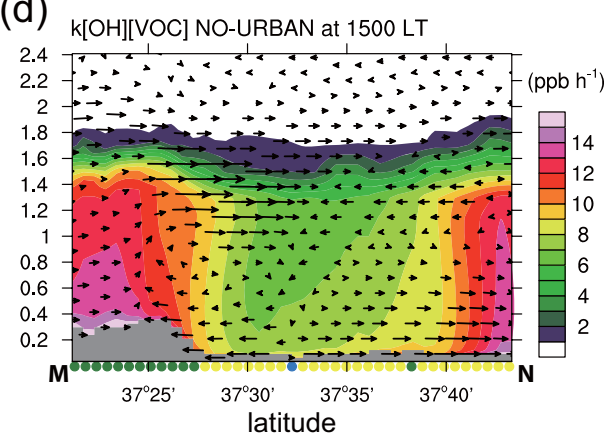

(f)

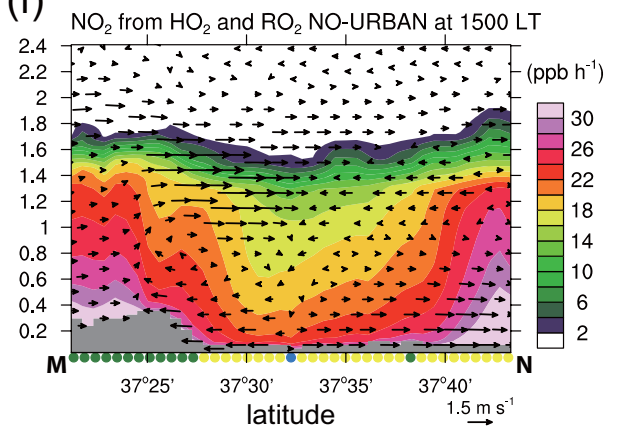

Fig. 11. Vertical cross sections of (a) OH chain length, (c) rate of reactions between $\mathrm{OH}$ and VOCs, (e) $\mathrm{NO}_{2}$ production from the reactions between $\mathrm{NO}$ and peroxy radicals $\left(\mathrm{HO}_{2}\right.$ and $\left.\mathrm{RO}_{2}\right)$, and wind along the line $\mathrm{M}-\mathrm{N}$ in Fig. 1d at 15:00 LT in the URBAN simulation. (b), (d), and (f) are the same as (a), (c), and (e), respectively, but for the NO-URBAN simulation. The color of circles on the x-axis corresponds to the color of the LULC in Fig. $1 \mathrm{~b}$.

to the low $\mathrm{NO}_{\mathrm{x}}$ and high BVOC levels, as can be inferred from the emission fields (Fig. 1c, d). Here, a $\mathrm{NO}_{\mathrm{x}}$ level below $\sim 15$ ppb (daily averaged $\mathrm{NO}_{\mathrm{x}}$ level over the surrounding rural area) is considered as the low $\mathrm{NO}_{\mathrm{x}}$ level. This air mass is characterized by high $\mathrm{O}_{3}$, low $\mathrm{NO}_{\mathrm{x}}$, high $\mathrm{BVOC}$, and high oxygenated VOC levels, and the $\mathrm{OH}$ level in the air mass is of course high (not shown). As the air mass that has different characteristics moves toward the urban area following the convergent flow, the rate of reactions between $\mathrm{OH}$ and VOCs $\left(\sum_{i} k_{i}[\mathrm{OH}]\left[\mathrm{VOC}_{i}\right]\right.$, hereafter denoted by $k[\mathrm{OH}][\mathrm{VOC}])$ increases in the regions where the urban breeze prevails (Fig. 11c). The reactions between $\mathrm{OH}$ and VOCs further produce peroxy radicals such as $\mathrm{HO}_{2}$ and $\mathrm{RO}_{2}$ and oxygenated VOCs. As the peroxy radicals oxidize NO to $\mathrm{NO}_{2}$ (Fig. 11e), the chemical production of $\mathrm{O}_{3}$ can be en- hanced there (Fig. 10e). In the NO-URBAN simulation, the supply of $\mathrm{NO}_{2}$ over the mountain by the valley-breeze circulation occurs continuously and thereby the chemical production of $\mathrm{O}_{3}$ is enhanced over the mountain where $\mathrm{NO}_{\mathrm{x}}$ emissions are very low (Fig. 10f). However, there are no significant changes in the contribution of the chemical process and in the chemical reaction rates associated with the valleybreeze circulation in the cropland area (Figs. 10f and 11b, d, f).

In the city center where $\mathrm{NO}_{\mathrm{x}}$ emissions are high, the $\mathrm{OH}$ chain length is short in both simulations (Fig. 11a, b). In the $\mathrm{NO}_{\mathrm{x}}$-rich area such as in the city center, $\mathrm{OH}$ is predominantly removed by the reaction with $\mathrm{NO}_{2}$ (Seinfeld and Pandis, 2006). Thus, the chemical production of $\mathrm{O}_{3}$ in the city center is reduced relative to that in the surroundings. 
However, in the upper urban boundary layer in the city center $\left(\sim 37^{\circ} 35^{\prime} \mathrm{N}\right)$, the slightly enhanced chemical production of $\mathrm{NO}_{2}$ from peroxy radicals (Fig. 11e) and the enhanced chemical production of $\mathrm{O}_{3}$ (Fig. 10e) are seen in the URBAN simulation. The upward transport of $\mathrm{O}_{3}$ precursors (both $\mathrm{NO}_{\mathrm{x}}$ and VOCs) by the rising motion of the urban-breeze circulation is responsible for the enhanced chemical production of $\mathrm{O}_{3}$ in the upper urban boundary layer. Note that due to the co-location of anthropogenic sources of $\mathrm{NO}_{\mathrm{x}}$ and VOCs the transport of anthropogenic VOCs is found to be similar to that of $\mathrm{NO}_{\mathrm{x}}$ (not shown).

\subsection{Ozone production efficiency}

The ozone production efficiency (OPE) can be defined as the number of $\mathrm{O}_{3}$ molecules photochemically produced by a molecule of $\mathrm{NO}_{\mathrm{x}}$ before it is lost from the $\mathrm{NO}_{\mathrm{x}}-\mathrm{O}_{3}$ cycle (Zaveri et al., 2003). The OPE was first introduced by Liu et al. (1987) and has been used to study air quality (e.g. Nunnermacker et al., 2000; Kleinman et al., 2002; Daum et al., 2003; Zaveri et al., 2003; Lei et al., 2007). The OPE has been reported to range from 2-8 in urban areas to 46 (Wood et al., 2009). In the present analysis, the net chemical production of $\mathrm{O}_{\mathrm{x}}$ instead of $\mathrm{O}_{3}$ is used not to take into account the conversion between $\mathrm{NO}_{2}$ and $\mathrm{O}_{3}$. Following Lei et al. (2007), the OPE is calculated as the ratio of net chemical production of $\mathrm{O}_{\mathrm{x}}$ to that of $\mathrm{NO}_{\mathrm{z}}$, i.e. $\mathrm{P}\left(\mathrm{O}_{\mathrm{x}}\right) / \mathrm{P}\left(\mathrm{NO}_{\mathrm{z}}\right)$, where $\mathrm{NO}_{\mathrm{z}}$ is the $\mathrm{NO}_{\mathrm{x}}$ oxidation products. The near-surface OPE as a function of near-surface $\mathrm{NO}_{\mathrm{x}}$ concentration in the urban analysis area is depicted in Fig. 12. The $k[\mathrm{OH}][\mathrm{VOC}]$ is represented by color. In both simulations, the OPE tends to decrease as $\mathrm{NO}_{\mathrm{x}}$ concentration increases, as previously demonstrated in many studies for polluted areas (e.g. Kleinman et al., 2002; Lei et al., 2007). As can be expected from the higher $\mathrm{O}_{3}$ concentration in the URBAN simulation, the average OPE in the URBAN simulation (6.9) is higher than that in the NO-URBAN simulation (6.0). The average $k[\mathrm{OH}][\mathrm{VOC}]$ is also higher in the URBAN simulation $\left(10.4 \mathrm{ppbh}^{-1}\right)$ than in the NOURBAN simulation $\left(9.4 \mathrm{ppbh}^{-1}\right)$. In particular, air masses characterized by high OPE $(>\sim 6)$, a relatively low $\mathrm{NO}_{\mathrm{x}}$ level ( $<\sim 20 \mathrm{ppb})$, and high $k[\mathrm{OH}][\mathrm{VOC}]\left(>\sim 10 \mathrm{ppbh}^{-1}\right)$ appear in the URBAN simulation. Such air masses are also seen in the NO-URBAN simulation but to a lesser extent relative to those in the URBAN simulation.

To examine the characteristics of the air masses yielding the high OPE, the scatter diagrams in region $\mathrm{A}$ in the two simulations are shown in Fig. 13a, b. In Fig. 13, the color of outer circles indicates $k[\mathrm{OH}][\mathrm{VOC}]$ at 11:00 LT and the color of inner circles indicates that at 15:00 LT. Region A is characterized as being directly influenced by the urbanbreeze circulation (see Fig. 3e). The OPE in region A is higher in the URBAN simulation (8.8 on average) than in the NO-URBAN simulation ( 6.0 on average). The air masses in region $\mathrm{A}$ are characterized by a relatively low $\mathrm{NO}_{\mathrm{x}}$ level and high $k[\mathrm{OH}][\mathrm{VOC}]$, which are similar to the air masses in
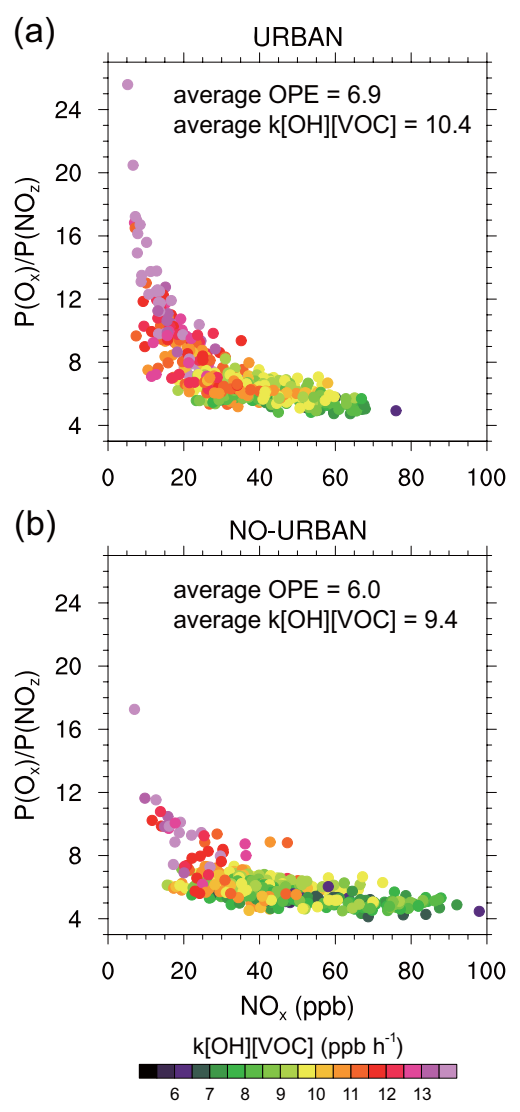

Fig. 12. Scatter diagrams of ozone production efficiency [OPE, calculated as $\mathrm{P}\left(\mathrm{O}_{\mathrm{x}}\right) / \mathrm{P}\left(\mathrm{NO}_{\mathrm{z}}\right)$ ] and $\mathrm{NO}_{\mathrm{x}}$ concentration at 15:00 LT in the urban analysis area in the (a) URBAN and (b) NO-URBAN simulations. The color of circles indicates the rate of reactions between $\mathrm{OH}$ and VOCs (denoted by $k[\mathrm{OH}][\mathrm{VOC}])$. The unit of $k[\mathrm{OH}][\mathrm{VOC}]$ is $\mathrm{ppbh}^{-1}$.

the surroundings (e.g. in the mountainous areas where BVOC emissions are significant). Previously, the significantly high OPE was observed in regions with high isoprene emissions (e.g. Luria et al., 2000; Ryerson et al., 2001). As compared with $k[\mathrm{OH}][\mathrm{VOC}]$ at $11: 00 \mathrm{LT}\left(6.7 \mathrm{ppbh}^{-1}\right.$ on average), it is confirmed that owing to the advection of the air masses from the surroundings $k[\mathrm{OH}][\mathrm{VOC}]$ increases significantly at 15:00 LT (12.0 $\mathrm{ppb} \mathrm{h}^{-1}$ on average). This advection effect is also confirmed by comparing the results in region $\mathrm{A}$ with those in region $\mathrm{C}$ where the urban-breeze circulation is less predominant. The difference in $k[\mathrm{OH}][\mathrm{VOC}]$ at 15:00 LT between the URBAN and NO-URBAN simulations in region C is not as evident as that in region A. The air masses in region $\mathrm{A}$ in the NO-URBAN simulation are characterized by low OPE, a high $\mathrm{NO}_{\mathrm{x}}$ level, and low $k[\mathrm{OH}][\mathrm{VOC}]$ relative to those in the URBAN simulation. From the scatter diagram, it is found that the enhanced chemical production of $\mathrm{O}_{3}$ associated with the urban-breeze circulation examined through the example in Figs. 10 and 11 is also revealed in other regions where the urban-breeze circulation prevails. Thus, it is 


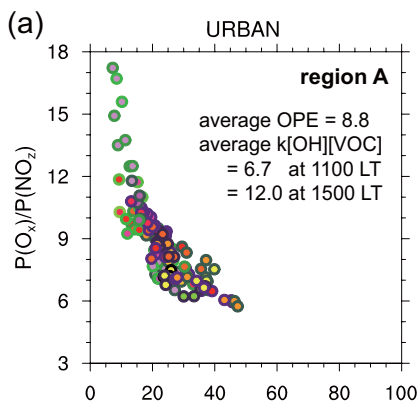

(c)

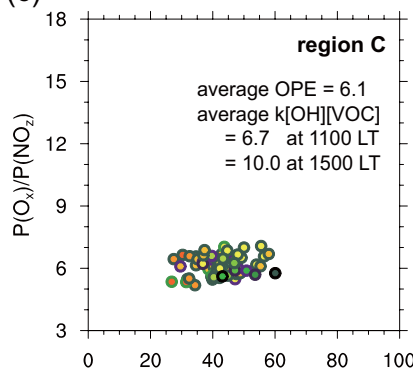

(e)

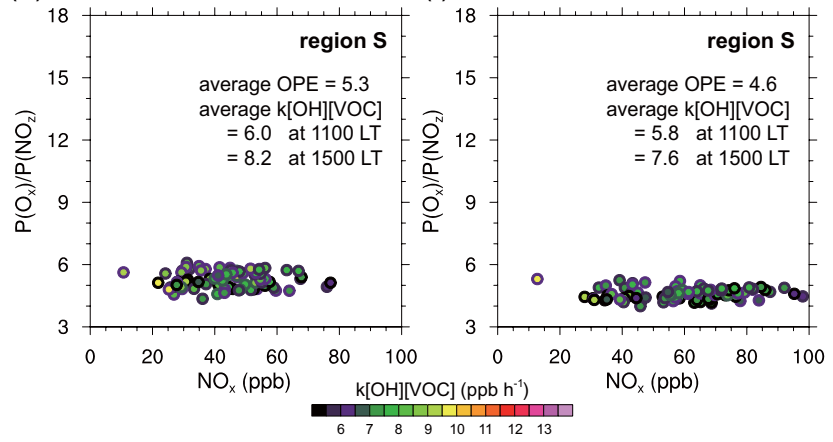

Fig. 13. Scatter diagrams of ozone production efficiency [OPE, calculated as $\left.\mathrm{P}\left(\mathrm{O}_{\mathrm{x}}\right) / \mathrm{P}\left(\mathrm{NO}_{\mathrm{z}}\right)\right]$ and $\mathrm{NO}_{\mathrm{x}}$ concentration at 15:00 LT in the (a) URBAN and (b) NO-URBAN simulations in region A, the (c) URBAN and (d) NO-URBAN simulations in region $\mathrm{C}$, and the (e) URBAN and (f) NO-URBAN simulations in region $\mathrm{S}$. The values of average OPE are the values at 15:00 LT. The color of outer (inner) circles indicates the rate of reactions between $\mathrm{OH}$ and VOCs, denoted by $k[\mathrm{OH}][\mathrm{VOC}]$, at 11:00 (15:00) LT. The unit of $k[\mathrm{OH}][\mathrm{VOC}]$ is $\mathrm{ppbh}^{-1}$.

concluded that the high OPE in the urban area is largely attributed to the advection of the air masses from the surroundings by the urban-breeze circulation.

For region $\mathrm{C}$ where $\mathrm{NO}_{\mathrm{x}}$ emissions are high, the OPE and $k[\mathrm{OH}][\mathrm{VOC}]$ in the afternoon are slightly higher in the URBAN simulation than in the NO-URBAN simulation (Fig. 13c, d). Region $\mathrm{C}$ coincides with the city center and is characterized by relatively strong UHI intensity (not shown). The ABL height in region $\mathrm{C}$ is high. That is, the dilution effect in the urban boundary layer is large in region $C$. As a result, the $\mathrm{NO}_{\mathrm{x}}$ level in this region is lower in the URBAN simulation than in the NO-URBAN simulation. A decrease in $\mathrm{NO}_{\mathrm{x}}$ level can reduce the amount of $\mathrm{OH}$ terminated and thereby increase the OPE. Yet, owing to the still high $\mathrm{NO}_{\mathrm{x}}$ level, the dilution effect associated with the urban-modified boundary layer appears to be small relative to the advection effect associated with the urban-breeze circulation examined in region $A$.

However, the dilution effect can be large in the regions where the sea breeze prevails (e.g. in region S). As demonstrated in Ryu and Baik (2012), the depth of the seabreeze inflow layer can increase significantly in the urban area owing to the UHI effect. When comparing Fig. 13e with Fig. 13f, higher OPE, a lower $\mathrm{NO}_{\mathrm{x}}$ level, and higher $k[\mathrm{OH}][\mathrm{VOC}]$ are found in the URBAN simulation. To examine the impacts of the urban-modified sea breeze, the vertical cross sections of $\mathrm{NO}_{\mathrm{x}}$ and $\mathrm{O}_{3}$ concentrations and wind along the line E-F (Fig. 1c) are presented in Fig. 14. The location of the sea-breeze front is indicated by a blue arrow. The $\mathrm{NO}_{\mathrm{x}}$ level in region $\mathrm{S}$ is significantly lower in the URBAN simulation than in the NO-URBAN simulation. The relatively strong mixing in the urban boundary layer embedded in the sea-breeze inflow layer contributes markedly to the low $\mathrm{NO}_{\mathrm{x}}$ level. An elevated $\mathrm{O}_{3}$ level behind region $\mathrm{S}$ is seen in Fig. 14c. Even though the $\mathrm{O}_{3}$-rich air is advected following the sea-breeze inflow, $\mathrm{O}_{3}$ concentration decreases in the urban area where $\mathrm{NO}_{\mathrm{x}}$ emissions are high (e.g. in region $\mathrm{S})$. In region $\mathrm{S}$, the reduced $\mathrm{O}_{3}$ destruction by $\mathrm{NO}$ and the relatively high $\mathrm{OH}$ level (not shown) result in the high $\mathrm{O}_{3}$ concentration and the high OPE. In addition to region $\mathrm{S}$, in region $\mathrm{C}$ a deeper boundary layer, a lower $\mathrm{NO}_{\mathrm{x}}$ level, and a higher $\mathrm{O}_{3}$ concentration in the URBAN simulation than in the NO-URBAN simulation are seen in Fig. 14.

\section{Summary and conclusions}

In this case study, the impacts of urban land-surface forcing on ozone air quality in the Seoul metropolitan area were examined. Under fair weather conditions, the temperature excess in the urban area (urban heat island) significantly modifies the boundary layer characteristics/structures and local circulations. On average, $\mathrm{O}_{3}$ concentration is $16 \mathrm{ppb}$ higher in the nighttime and is $13 \mathrm{ppb}$ higher in the daytime in the URBAN simulation than in the NO-URBAN simulation even though the emissions in the two simulations are the same as each other. Owing to the intense heating from the urban surface, the turbulent mixing is enhanced and the boundary layer height increases correspondingly. Pollutants are more diluted and well mixed in the deep urban boundary layer, and this results in reduced $\mathrm{O}_{3}$ destruction by $\mathrm{NO}$. Therefore, $\mathrm{O}_{3}$ concentration is higher in the URBAN simulation than in the NO-URBAN simulation. This dilution effect dominates especially in the late afternoon, in the nighttime, and under the influence of the sea breeze.

The urban-breeze circulation is induced by the urban heat island, and this circulation prevails in the afternoon against the valley-breeze circulation that is predominant in the mid- 
(a) $\mathrm{NO}_{x}$ URBAN at $1500 \mathrm{LT}$

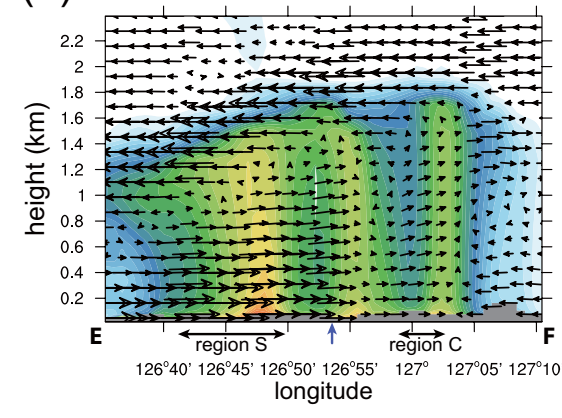

(c) $O_{3}$ URBAN at 1500 LT

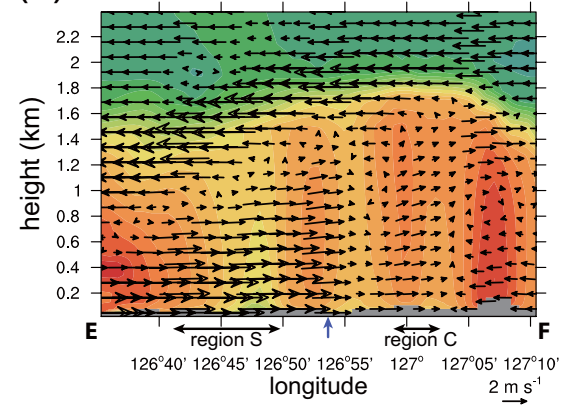

(b) $\mathrm{NO}_{x}$ NO-URBAN at $1500 \mathrm{LT}$

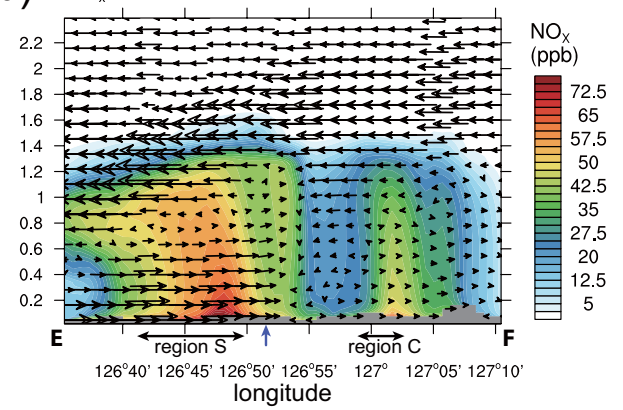

(d) $\mathrm{O}_{3}$ NO-URBAN at $1500 \mathrm{LT}$

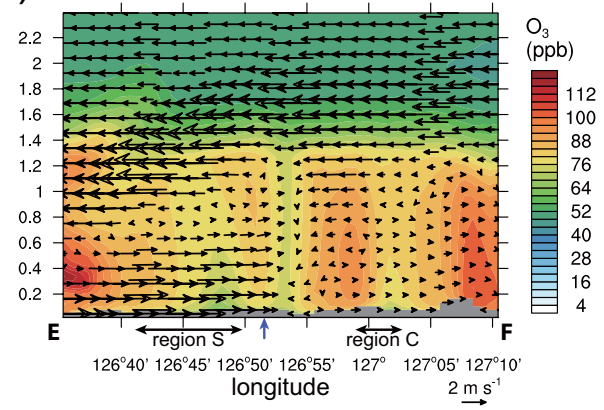

Fig. 14. Vertical cross sections of (a) $\mathrm{NO}_{\mathrm{x}}$ and (c) $\mathrm{O}_{3}$ concentrations and wind along the line $\mathrm{E}-\mathrm{F}$ in Fig. 1c at 15:00 LT in the URBAN simulation. (b) and (d) are the same as (a) and (c), respectively, but for the NO-URBAN simulation. The blue arrow indicates the location of the sea-breeze front.

to late morning. The change in prevailing local circulation from the valley-breeze circulation to the urban-breeze circulation in the afternoon acts to effectively recirculate pollutants. In the mid- to late morning, pollutants such as $\mathrm{NO}_{2}$ are advected over the mountains by the upslope wind. This contributes to the build-up of $\mathrm{O}_{3}$ over the mountains in conjunction with BVOC emissions there. As the prevailing local circulation in the afternoon turns to the urban-breeze circulation that is opposite to the valley-breeze circulation, the $\mathrm{O}_{3}$-rich air over the mountains is brought into the urban area. Hence, $\mathrm{O}_{3}$ concentration in the regions where the urban breeze prevails increases directly by the advection of the $\mathrm{O}_{3}$-rich air. In addition, the advection of the air masses, characterized by low $\mathrm{NO}_{\mathrm{x}}$ and high BVOC levels and long $\mathrm{OH}$ chain length, from the surroundings by the urban-breeze circulation increases the ozone production efficiency in the urban area, thus enhancing chemical production of $\mathrm{O}_{3}$. It is concluded that the urban-breeze circulation that prevails against the valley-breeze circulation exerts significant influences on not only the advection of $\mathrm{O}_{3}$ but also the chemical production of $\mathrm{O}_{3}$ under the circumstances in which both anthropogenic and biogenic (natural) emissions play important roles in $\mathrm{O}_{3}$ formation. Furthermore, the upward transport of $\mathrm{O}_{3}$ precursors by the rising motion of the urban-breeze circulation contributes to the enhanced chemical production of $\mathrm{O}_{3}$ in the upper urban boundary layer.
This study demonstrated that urban land-surface forcing can increase $\mathrm{O}_{3}$ concentration in the urban area under the fair weather conditions that are conducive to both strong urban heat island and elevated $\mathrm{O}_{3}$ levels. In this study, we examined one case in which the large-scale synoptic forcing was weak. The degrees of the impacts of urban land-surface forcing on local meteorology and air quality can vary depending on the magnitude of large-scale synoptic forcing. Thus, further studies under various synoptic conditions are desired.

\section{Supplementary material related to this article is available online at: http://www.atmos-chem-phys.net/13/ 2177/2013/acp-13-2177-2013-supplement.pdf.}

Acknowledgements. The authors are grateful to two anonymous reviewers for providing valuable comments on this work. This work was supported by the National Research Foundation of Korea (NRF) grant funded by the Korea Ministry of Education, Science and Technology (MEST) (No. 2012-0005674).

Edited by: C. H. Song 


\section{References}

Banta, R. M., Senff, C. J., Nielsen-Gammon, J., Darby, L. S., Ryerson, T. B., Alvarez, R. J., Sandberg, S. P., Williams, E. J., and Trainer, M.: A bad air day in Houston, B. Am. Meteorol. Soc., 86, 657-669, 2005.

Byun, D. and Schere, K. L.: Review of the governing equations, computational algorithms, and other components of the Models3 Community Multiscale Air Quality (CMAQ) modeling system, Appl. Mech. Rev., 59, 51-77, 2006.

Carter, W. P. L.: Documentation of the SAPRC-99 chemical mechanism for VOC reactivity assessment, Final Report to California Air Resources Board, Contract 92-329 and Contract 95-308, Air Pollution Research Center and College of Engineering Center for Environmental Research and Technology, University of California Riverside, California, 2000.

Civerolo, K., Hogrefe, C., Lynn, B., Rosenthal, J., Ku, J.-Y., Solecki, W., Cox, J., Small, C., Rosenzweig, C., Goldberg, R., Knowlton, K., and Kinney, P.: Estimating the effects of increased urbanization on surface meteorology and ozone concentrations in the New York City metropolitan region, Atmos. Environ., 41, 1803-1818, 2007.

Daum, P. H., Kleinman, L. I., Springston, S. R., Nunnermacker, L. J., Lee, Y.-N., Weinstein-Lloyd, J., Zheng, J., and Berkowitz, C. M.: A comparative study of $\mathrm{O}_{3}$ formation in the Houston urban and industrial plumes during the 2000 Texas Air Quality Study, J. Geophys. Res., 108, 4715, doi:10.1029/2003JD003552, 2003.

Duncan, B. N., Yoshida, Y., Olson, J. R., Sillman, S., Martin, R. V., Lamsal, L., Hu, Y., Pickering, K. E., Retscher, C., Allen, D. J., and Crawford, J. H.: Application of OMI observations to a spacebased indicator of $\mathrm{NO}_{\mathrm{x}}$ and VOC controls on surface ozone formation, Atmos. Environ., 44, 2213-2223, 2010.

Fast, J. D. and Zhong, S.: Meteorological factors associated with inhomogeneous ozone concentrations within the Mexico City basin, J. Geophys. Res., 103, 18927-18946, 1998.

Fast, J. D., Doran, J. C., Shaw, W. J., Coulter, R. L., and Martin, T. J.: The evolution of the boundary layer and its effect on air chemistry in the Phoenix area, J. Geophys. Res., 105, 22833 22848, 2000.

Foley, K. M., Roselle, S. J., Appel, K. W., Bhave, P. V., Pleim, J. E., Otte, T. L., Mathur, R., Sarwar, G., Young, J. O., Gilliam, R. C., Nolte, C. G., Kelly, J. T., Gilliland, A. B., and Bash, J. O.: Incremental testing of the Community Multiscale Air Quality (CMAQ) modeling system version 4.7, Geosci. Model Dev., 3, 205-226, doi:10.5194/gmd-3-205-2010, 2010.

Gipson, G. L.: Science Algorithms of the EPA Models-3 Community Multiscale Air Quality (CMAQ) Modeling System: Process analysis, EPA/600/R-99/030, US EPA, online available at: http://www.epa.gov/asmdnerl/CMAQ/ch16.pdf, 37 pp., 1999.

Guenther, A., Karl, T., Harley, P., Wiedinmyer, C., Palmer, P. I., and Geron, C.: Estimates of global terrestrial isoprene emissions using MEGAN (Model of Emissions of Gases and Aerosols from Nature), Atmos. Chem. Phys., 6, 3181-3210, doi:10.5194/acp-63181-2006, 2006.

Henne, S., Furger, M., Nyeki, S., Steinbacher, M., Neininger, B., de Wekker, S. F. J., Dommen, J., Spichtinger, N., Stohl, A., and Prévôt, A. S. H.: Quantification of topographic venting of boundary layer air to the free troposphere, Atmos. Chem. Phys., 4, 497509, doi:10.5194/acp-4-497-2004, 2004.
Hidalgo, J., Pigeon, G., and Masson, V.: Urban-breeze circulation during the CAPITOUL experiment: Observational data analysis approach, Meteorol. Atmos. Phys., 102, 223-241, 2008.

Hong, S.-Y., Noh, Y., and Dudhia, J.: A new vertical diffusion package with an explicit treatment of entrainment processes, Mon. Weather Rev., 134, 2318-2341, 2006.

Houyoux, M. R., Vukovich, J. M., Coats, C. J., Wheeler, N. J. M., and Kasibhatla, P. S.: Emission inventory development and processing for the Seasonal Model for Regional Air Quality (SMRAQ) project, J. Geophys. Res., 105, 9079-9090, 2000.

Jeffries, H. E. and Tonnesen, S.: A comparison of two photochemical reaction mechanisms using mass balance and process analysis, Atmos. Environ., 28, 2991-3003, 1994.

Jiang, X., Wiedinmyer, C., Chen, F., Yang, Z.-L., and Lo, J. C.F.: Predicted impacts of climate and land use change on surface ozone in the Houston, Texas, area, J. Geophys. Res., 113, D20312, doi:10.1029/2008JD009820, 2008.

Khiem, M., Ooka, R., Hayami, H., Yoshikado, H., Huang, H., and Kawamoto, Y.: Process analysis of ozone formation under different weather conditions over the Kanto region of Japan using the MM5/CMAQ modelling system, Atmos. Environ., 44, 44634473, 2010.

Kim, S., Moon, N., and Byun, D. W.: Korea emissions inventory processing using the US EPA's SMOKE system, Asian J. Atmos. Environ., 2, 34-46, 2008.

Kleinman, L. I., Daum, P. H., Lee, Y.-N., Nunnermacker, L. J., Springston, S. R., Weinstein-Lloyd, J., and Rudolph J.: Ozone production efficiency in an urban area, J. Geophys. Res., 107, 4733, doi:10.1029/2002JD002529, 2002.

Lei, W., de Foy, B., Zavala, M., Volkamer, R., and Molina, L. T.: Characterizing ozone production in the Mexico City Metropolitan Area: a case study using a chemical transport model, Atmos. Chem. Phys., 7, 1347-1366, doi:10.5194/acp-7-1347-2007, 2007.

Lemonsu, A. and Masson, V.: Simulation of a summer urban breeze over Paris, Bound. Lay. Meteorol., 104, 463-490, 2002.

Levy, I., Dayan, U., and Mahrer, Y.: A five-year study of coastal recirculation and its effect on air pollutants over the East Mediterranean region, J. Geophys. Res., 113, D16121, doi:10.1029/2007JD009529, 2008.

Liu, S. C., Trainer, M., Fehsenfeld, F. C., Parrish, D. D., Williams, E. J., Fahey, D. W., Hübler, G., and Murphy, P. C.: Ozone production in the rural troposphere and the implications for regional and global ozone distributions, J. Geophys. Res., 92, 4191-4207, 1987.

Lu, R. and Turco, R. P.: Air pollutant transport in a coastal environment. Part I: Two-dimensional simulations of sea-breeze and mountain effects, J. Atmos. Sci., 51, 2285-2308, 1994.

Luria, M., Tanner, R. L., Imhoff, R. E., Valente, R. J., Bailey, E. M., and Mueller, S. F.: Influence of natural hydrocarbons on ozone formation in an isolated power plant plume, J. Geophys. Res., 105, 9177-9188, 2000.

Makar, P. A., Zhang, J., Gong, W., Stroud, C., Sills, D., Hayden, K. L., Brook, J., Levy, I., Mihele, C., Moran, M. D., Tarasick, D. W., He, H., and Plummer, D.: Mass tracking for chemical analysis: the causes of ozone formation in southern Ontario during BAQS-Met 2007, Atmos. Chem. Phys., 10, 11151-11173, doi:10.5194/acp-10-11151-2010, 2010. 
Mao, J., Ren, X., Chen, S., Brune, W. H., Chen, Z., Martinez, M., Harder, H., Lefer, B., Rappenglück, B., Flynn, J., and Leuchner, M.: Atmospheric oxidation capacity in the summer of Houston 2006: Comparison with summer measurements in other metropolitan studies, Atmos. Environ., 44, 4107-4115, 2010.

Martins, D. K., Stauffer, R. M., Thompson, A. M., Knepp, T. N., and Pippin, M.: Surface ozone at a coastal suburban site in 2009 and 2010: Relationships to chemical and meteorological processes, J. Geophys. Res., 117, D05306, doi:10.1029/2011JD016828, 2012.

Miao, S., Chen, F., LeMone, M. A., Tewari, M., Li, Q., and Wang, Y.: An observational and modeling study of characteristics of urban heat island and boundary layer structures in Beijing, J. Appl. Meteorol. Climatol., 48, 484-501, 2009.

Moon, N., Kim, S., Byun, D. W., and Joe, Y.: Air Quality Modeling System I - Development of Emissions Preparation System with the CAPSS, KEI Rep. 2006-RE-11, Korea Environment Institute, Seoul, 95 pp., 2006.

Nunnermacker, L. J., Kleinman, L. I., Imre, D., Daum, P. H., Lee, Y.-N., Lee, J. H., Springston, S. R., Newman, L., and Gillani, $\mathrm{N}$.: $\mathrm{NO}_{\mathrm{y}}$ lifetimes and $\mathrm{O}_{3}$ production efficiencies in urban and power plant plumes: Analysis of field data, J. Geophys. Res., 105, 9165-9176, 2000.

Oh, I.-B., Kim, Y.-K., Lee, H., and Kim, C.-H.: An observational and numerical study of the effects of the late sea breeze on ozone distributions in the Busan metropolitan area, Korea, Atmos. Environ., 40, 1284-1298, 2006.

Pleim, J. E.: A combined local and nonlocal closure model for the atmospheric boundary layer. Part I: Model description and testing, J. Appl. Meteorol. Climatol., 46, 1383-1395, 2007.

Ryerson, T. B., Trainer, M., Holloway, J. S., Parrish, D. D., Huey, L. G., Sueper, D. T., Frost, G. J., Donnelly, S. G., Schauffler, S., Atlas, E. L., Kuster, W. C., Goldan, P. D., Hübler, G., Meagher, J. F., and Fehsenfeld, F. C.: Observations of ozone formation in power plant plumes and implications for ozone control strategies, Science, 292, 719-723, 2001.

Ryu, Y.-H. and Baik, J.-J.: Daytime local circulations and their interactions in the Seoul metropolitan area, J. Appl. Meteorol. Climatol., doi:10.1175/JAMC-D-12-0157.1, 2012.

Ryu, Y.-H., Baik, J.-J., and Lee, S.-H.: A new single-layer urban canopy model for use in mesoscale atmospheric models, J. Appl. Meteorol. Climatol., 50, 1773-1794, 2011.

Sarrat, C., Lemonsu, A., Masson, V., and Guedalia, D.: Impact of urban heat island on regional atmospheric pollution, Atmos. Environ., 40, 1743-1758, 2006.

Seinfeld, J. H. and Pandis, S. N.: Atmospheric Chemistry and Physics: From Air Pollution to Climate Change, Second Edition, Wiley-Interscience, New York, 1203 pp., 2006.
Sheehy, P. M., Volkamer, R., Molina, L. T., and Molina, M. J.: Oxidative capacity of the Mexico City atmosphere - Part 2: $\mathrm{A} \mathrm{RO}_{\mathrm{x}}$ radical cycling perspective, Atmos. Chem. Phys., 10, 6993-7008, doi:10.5194/acp-10-6993-2010, 2010.

Skamarock, W. C., Klemp, J. B., Dudhia, J., Gill, D. O., Barker, D. M., Duda, M. G., Huang, X.-Y., Wang, W., and Powers, J. G.: A Description of the Advanced Research WRF Version 3, NCAR Tech. Note NCAR/TN-475+STR, 2008.

USEPA: Guideline for Regulatory Application of the Urban Airshed Model, US EPA Report No. EPA-450/4-91-013, Office of Air Quality Planning and Standards, Technical Support Division, Research Triangle Park, North Carolina, USA, 1991.

Wang, X. M., Lin, W. S., Yang, L. M., Deng, R. R., and Lin, H.: A numerical study of influences of urban land-use change on ozone distribution over the Pearl River Delta region, China, Tellus, 59B, 633-641, 2007.

Wang, X., Chen, F., Wu, Z., Zhang, M., Tewari, M., Guenther, A., and Wiedinmyer, C.: Impacts of weather conditions modified by urban expansion on surface ozone: Comparison between the Pearl River Delta and Yangtze River Delta regions, Adv. Atmos. Sci., 26, 962-972, 2009.

Wong, K. K. and Dirks, R. A.: Mesoscale perturbations on airflow in the urban mixing layer, J. Appl. Meteorol., 17, 677-688, 1978.

Wood, E. C., Herndon, S. C., Onasch, T. B., Kroll, J. H., Canagaratna, M. R., Kolb, C. E., Worsnop, D. R., Neuman, J. A., Seila, R., Zavala, M., and Knighton, W. B.: A case study of ozone production, nitrogen oxides, and the radical budget in Mexico City, Atmos. Chem. Phys., 9, 2499-2516, doi:10.5194/acp-9-24992009, 2009.

Yamartino, R. J.: Nonnegative, conserved scalar transport using grid-cell-centered, spectrally constrained Blackman cubics for applications on a variable-thickness mesh, Mon. Weather Rev., 121, 753-763, 1993.

Zaveri, R. A., Berkowitz, C. M., Kleinman, L. I., Springston, S. R., Doskey, P. V., Lonneman, W. A., and Spicer, C. W.: Ozone production efficiency and $\mathrm{NO}_{\mathrm{x}}$ depletion in an urban plume: Interpretation of field observations and implications for evaluating $\mathrm{O}_{3}-\mathrm{NO}_{\mathrm{x}}-$ VOC sensitivity, J. Geophys. Res., 108, 4436, doi:10.1029/2002JD003144, 2003.

Zhang, Y., Wen, X.-Y., Wang, K., Vijayaraghavan, K., and Jacobson, M. Z.: Probing into regional $\mathrm{O}_{3}$ and particulate matter pollution in the United States: 2. An examination of formation mechanisms through a process analysis technique and sensitivity study, J. Geophys. Res., 114, D22305, doi:10.1029/2009JD011900, 2009. 